\begin{abstract}
VARIATIONS IN ANGIOSPERM LEAF VEIN DENSITY HAVE IMPLICATIONS FOR INTERPRETING LIFE FORM IN THE FOSSIL RECORD
\end{abstract}

\author{
by Camilla Crifò
}

This work analyzes leaf vein density variation in flowering plants and proposes it as a new tool to trace the first occurrence of angiosperms as canopy members in the fossil record. Comparisons of vein density between canopy and understorey plants show that vein density variation mainly reflects the position of the leaf in the canopy. Vein density values of a standing forest are reflected in its leaf litter, suggesting that a fossil floral assemblage is also representative of a past forest ecosystem. Vein density measurement on leaf cuticles from a Miocene fossil flora suggest that vein density can be successfully measured on fossils. Comparison of vein density distributions of a leaf litter assemblage and those of several Cretaceous-Paleocene paleofloras (132.35 to $58 \mathrm{Ma}$ ) suggests that angiosperms emerged in forest canopies at least $58 \mathrm{Ma}$. 


\title{
VARIATIONS IN ANGIOSPERM LEAF VEIN DENSITY HAVE IMPLICATIONS FOR INTERPRETING LIFE FORM IN THE FOSSIL RECORD
}

\author{
A thesis \\ Submitted to the \\ Faculty of Miami University \\ in partial fulfillment of \\ the requirements for the degree of \\ Master of Science \\ Department of Geology and Earth Environmental Science \\ by \\ Camilla Crifò \\ Miami University \\ Oxford, Ohio \\ 2013 \\ Advisor: Ellen Currano \\ Reader: James Hickey \\ Reader: Jason Rech
}




\section{TABLE OF CONTENTS}

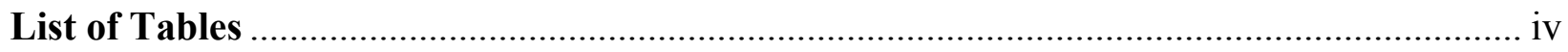

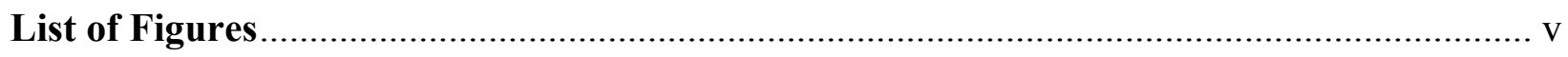

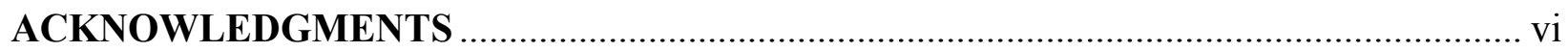

Section 1: Modern data, leaf litter, and fossil floras

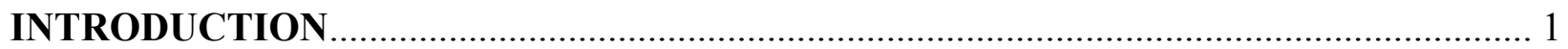

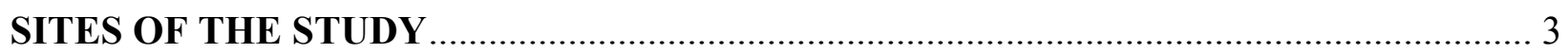

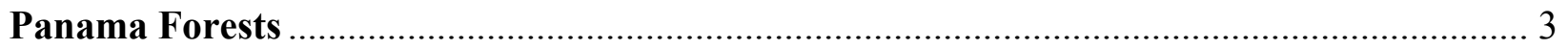

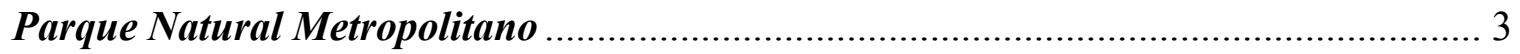

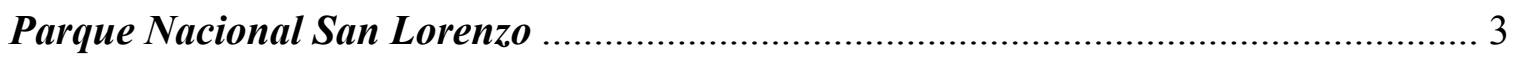

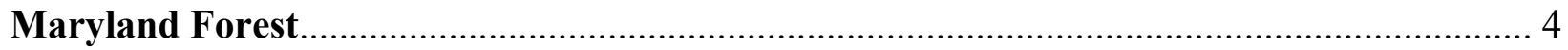

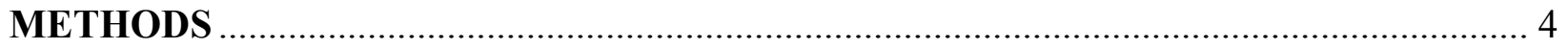

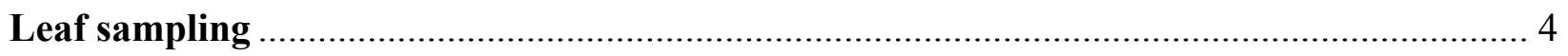

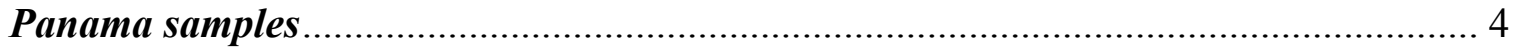

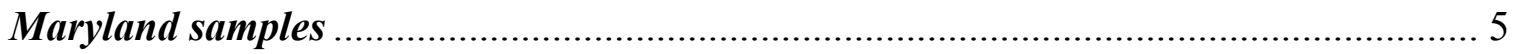

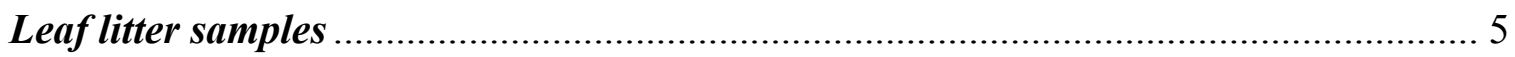

Laboratory protocol for leaf clearing, staining, and photographing .............................. 5

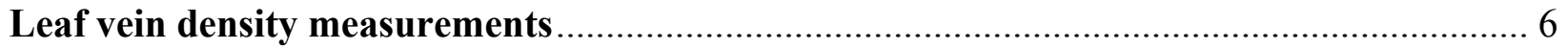

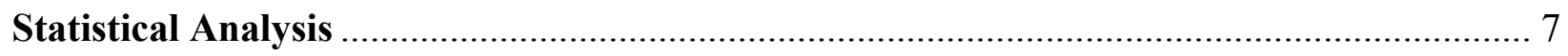

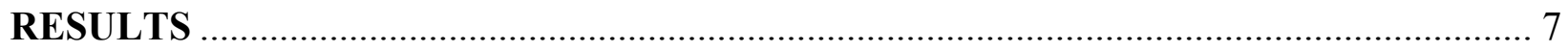

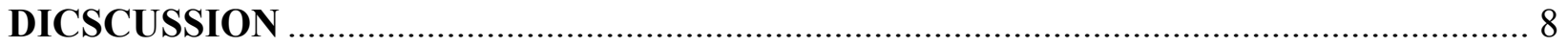

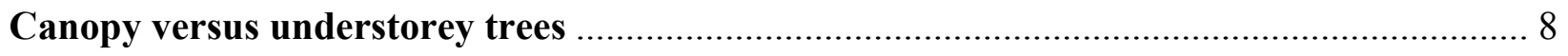

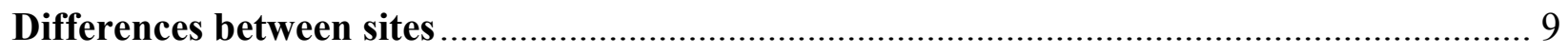

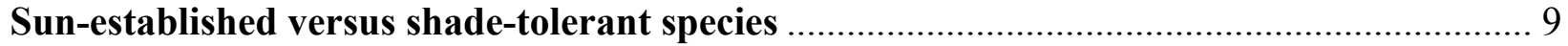

Early-diverging versus late-diverging angiosperms ................................................ 10

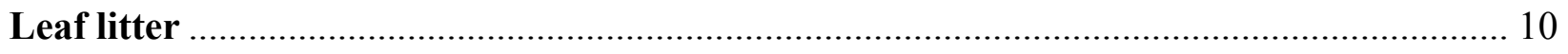

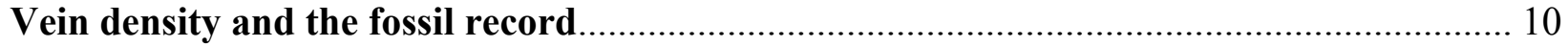

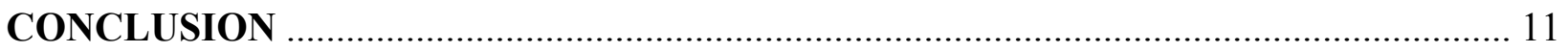


Section 2: The Mush Valley paleoflora: a preliminary case study of vein density as a proxy for canopy closure

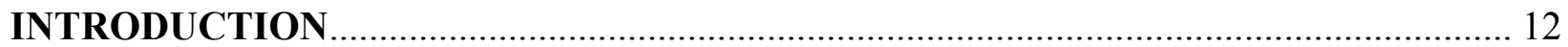

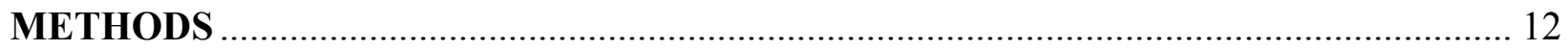

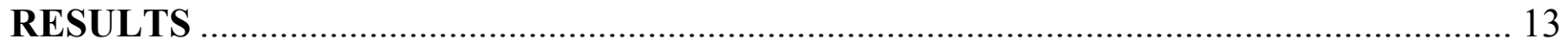

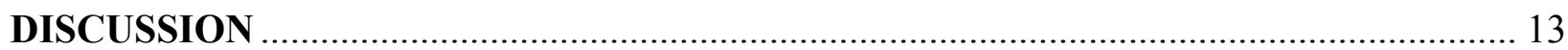

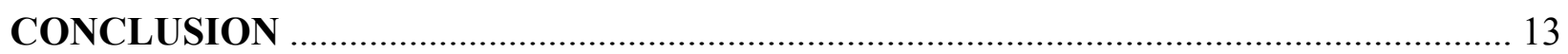

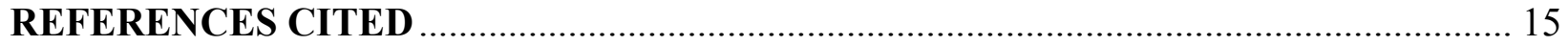

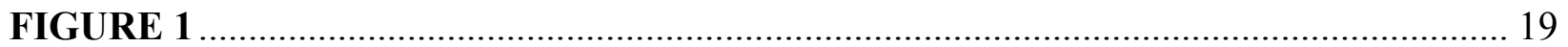

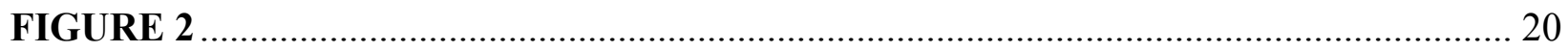

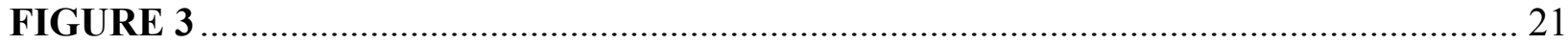

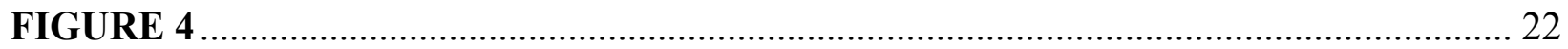

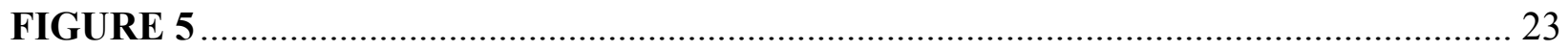

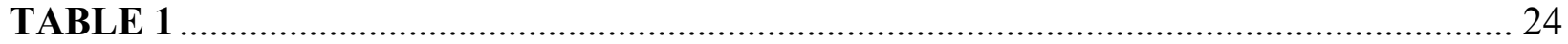

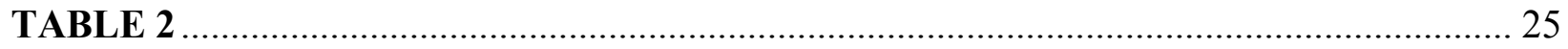

SUPPLEMENTARY MATERIAL

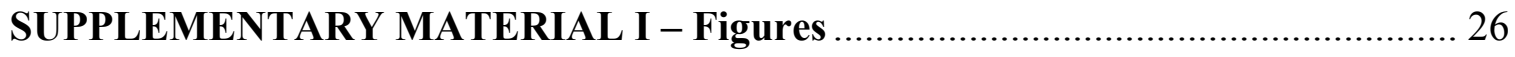

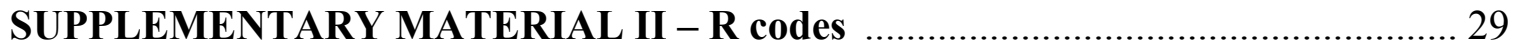

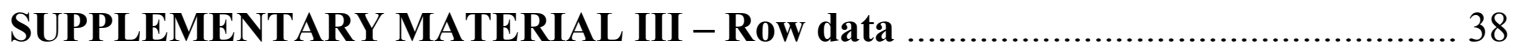




\section{List of Tables}

Table 1. Average $D_{\mathrm{v}}$ values of sun-demanding and shade tolerant species in both canopy and understorey strata in PNM, FTS, SERC forests, and all forests together (TOTAL).

Table 2. Table of specimen names, corresponding morphotypes, area measured and vein densities. 


\section{List of Figures}

Figure 1: Photo of a leaf of Miconia borealis (Melastomataceae) for vein density estimation.

Figure 2. Comparison of canopy and understorey at FTS, SERC, and PNM, and PNM litter.

Figure 3. Comparisons of the PNM litter and Cretaceous-Paleocene fossil floras.

Figure 4. Phylogenetic distribution of leaf vein density.

Figure 5. Comparisons of the PNM litter and the Mush Valley fossil assemblage. 


\section{ACKNOWLEDGMENTS}

This work was supported by a short-term fellowship at the Smithsonian Tropical Research Institute, a GSA Research Grant, a Kenneth E. \& Annie Caster Award of the Paleontological Society, awarded to Camilla Crifò, and NSF grant EAR-1052478 awarded to Ellen Currano. I thank Ellen Currano, Carlos Jaramillo, Andrés Baresch, Joe Wright, Mirna Samaniego, Enrique Moreno, Liliana Londoño, John Wallace, Geoffrey Parker, John Parker, and Sean McMahon. A special thanks to my committee members James Hickey and Jason Rech. 


\section{Section 1: Modern data, leaf litter, and Cretaceous-Paleocene fossil floras}

\section{INTRODUCTION}

Plant remains are usually found as isolated organs. Their morphology, anatomy, and taxonomy can provide information on species composition of ancient ecosystems, plant evolution, paleogeography, paleoecology, and paleoclimate, yet they have been scarcely used to infer the structure of past ecosystems. Hence, key questions for the history of terrestrial ecosystems, such as when angiosperms emerged and dominated forest canopies, remain unsolved. In this study I present vein density $\left(D_{\mathrm{v}}\right)$, a trait visible on fossil leaf imprints, as a tool to shed light on the origin of forest types. Vein density (the vein length per unit leaf area) correlates with transpiration capabilities (Brodribb et al., 2007) and maximum conductance to water vapor (Boyce et al., 2009). Increased $D_{\mathrm{v}}$ allows a leaf to deliver water as close to the epidermis as possible, overcoming the low hydraulic conductivity that characterizes the leaf mesophyll, and optimizing water transportation (Brodribb et al., 2007). Leaf $D_{\mathrm{v}}$ is also a tradeoff between the investments for more efficient transpiration and the costs of building vascular tissues (Noblin et al., 2008; Beerling and Franks, 2010; McKown et al., 2010). A four-fold increase in $D_{\mathrm{v}}$ during flowering plant evolution led to higher transpiration rates and contributed to the domination of this group in most terrestrial ecosystems (Boyce et al., 2009; Boyce and Leslie, 2012). de Boer et al., 2012 have interpreted angiosperms $D_{\mathrm{v}}$ increase as a response to the lower atmospheric humidity of the upper strata of the canopy and the falling $\mathrm{CO}_{2}$ concentration during the Cretaceous: in fact, under these conditions, high $D_{\mathrm{v}}$ may have allowed plants to face the higher transpirational demand associated with higher stomatal conductance typical of upper canopy environments (de Boer et al., 2012). Similarly, Feild et al., pointed out that the long-term decrease in $\mathrm{CO}_{2}$ and increase in $\mathrm{O}_{2}$ atmospheric concentrations during the Cretaceous represented an environmental pressure supporting higher vein density.

In some temperate and almost all tropical modern forests, angiosperms inhabit a wide range of microhabitats (strata), where they fulfill their different resource needs by a variety of ecological strategies (Denslow, 1987; Rijkers et al., 2000; Rueger et al., 2009). Some of these strategies are reflected in their life forms, morphology and physiology. Leaf trait variations between trees living in different forest strata have been documented and traditionally attributed to the local light regime (Sack \& Frole, 2006) or to differential hydraulic limitations at the top and bottom of the canopy (Zwienieck et al., 2004; Meinzer et al., 2008; Boyce, 2009; Cavaleri et 
al., 2010). In fact, the main limiting factor in angiosperm-dominated forests is light irradiance (Campanello et al., 2008), which decreases descending from the upper to the lower levels of the forest. Mulkey et al. (1996) documented a high light extinction (>90\%) below the uppermost canopy leaves of a tropical forest in Panama; similarly, light transmittance in the understorey of temperate deciduous forests drops below 5\% (Brown and Parker, 1994). In general, upper canopy leaves that have access to a higher light irradiance have higher stomatal density (Panditharathna et al., 2008; Yáñez-Espinosa et al., 2003), allowing higher transpiration rates and more efficient carbon gains (Rijkers et al., 2000). Similarly, shade-tolerant and sunestablished tropical forest species show differences in leaf hydraulic architecture, leaf conductance $\left(K_{\text {leaff }}\right)$ and leaf mass per area (LMA) (Sack et al., 2005; Sack and Frole, 2006; Campanello et al., 2008) associated to respectively lower (shade-tolerant) and higher (sunestablished) whole plant relative growth, carbon assimilation, and transpiration rates.

Here I test 3 hypotheses. (1) My first hypothesis is that differences between understory and canopy leaves are reflected in higher $D_{\mathrm{v}}$.values in the canopy than in the understorey, according to differential transpiration and metabolic needs at different forest strata. To test this, I have measured $D_{\mathrm{v}}$ variation among canopy and understorey plants in two forests in Panama and one in Maryland. (2) My second hypothesis is that the variation in $D_{\mathrm{v}}$ within a forest is reflected in its leaf litter. In order to know if both canopy and understorey values are present in the leaf litter, $D_{\mathrm{v}}$ values measured in a tropical leaf litter assemblage were compared to those of the corresponding standing forest. (3) My last hypothesis is that the first forests characterized by an angiosperm-dominated canopy present similar $D_{\mathrm{v}}$ values to modern forests. Present data from a tropical forest litter assemblage were compared with fossil data from Feild et al.'s (2011), which encompass a time period from the Hautaverian to the Paleocene (132.35 to $58 \mathrm{Ma})$. This comparison assumes that fossil flora assemblages reflect the forest as closely as litter assemblages do. Fossil and molecular data indicate that the rise of angiosperm-dominated forests took place either in the Late Cretaceous (Crane et al., 1995; Davis et al., 2005; Wang et al., 2009) or in the Paleocene (Bunrnham and Johnson, 2004; Wing et al., 2009; Wing et al., 2012). I propose vein density as a new tool to better define when the emergence of angiosperms as canopy members took place. 


\section{SITES OF THE STUDY}

\section{Panama Forests}

The two forest sites in Panama, Parque Natural Metropolitano (PNM) and Fort Sherman Crane (FTS) at the Parque Nacional San Lorenzo are located respectively on the Pacific and Caribbean coasts of Panama, near the cities of Panama and Colón.

\section{Parque Natural Metropolitano}

Parque Natural Metropolitano is located at $30 \mathrm{~m}$ above seal level on the Pacific coast, fifteen-minute drive from downtown Panama City $\left(8^{\circ} 59^{\prime} \mathrm{N}, 79^{\circ} 33^{\prime} \mathrm{W}\right)$. This site represents one of the few remaining tropical dry coastal forests in Central and South America and it has been protected since the construction on the Panama Canal (1903). Parque Natural Metropolitano is a tropical dry semi-deciduous rainforest with a mean annual rainfall of $1865 \mathrm{~mm}$ and mean annual temperature of $26.3^{\circ} \mathrm{C}$. The canopy is $30-40 \mathrm{~m}$ high and it is dominated by the species Anacardium excelsum (Anancardiaceae). Other abundant tree species are Luehea seemanii (Tilliaceae), Cordia alliodora (Boraginaceae), Ficus insipida (Moraceae) and Castilla elastica (Moraceae). 0.85 hectares of the forest are accessible by canopy crane, which is $42 \mathrm{~m}$ high with a $52 \mathrm{~m}$ long arm. 316 trees with a minimum diameter at breast height (dbh) of $10 \mathrm{~cm}$ have been censored and mapped in a 1-hectar-plot area surrounding the crane. Of the 284 species of trees present in the park, 36 species, belonging to 20 families, are reachable by the crane (STRI, 2013).

\section{Parque Nacional San Lorenzo}

Parque Nacional San Lorenzo (Fort Sherman Crane, FTS) is located $130 \mathrm{~m}$ above sea level on the Caribbean coast, near the city of Colón $\left(9^{\circ} 17^{\prime} \mathrm{N}, 79^{\circ} 58^{\prime} \mathrm{W}\right)$. This forest is 300 years old and is part of the Mesoamerican Biological Corridor and the forested area of the Panama Canal Basin. After having been used as a jungle warfare-training site by the U.S. army in the second half on the 1900's, the site was declared a protected area. Parque Nacional San Lorenzo is a tropical evergreen humid rainforest with annual rainfall of $3152 \mathrm{~mm}$ and a mean annual temperature of $25.8^{\circ} \mathrm{C}$. The canopy is $35-45 \mathrm{~m}$ high and it is dominated by the species Brosimum utile (Moraceae) and Manilkara bidentata (Sapotaceae). 0.92 hectares of the forest are accessible by the crane, which is $52 \mathrm{~m}$ high with a $54 \mathrm{~m}$ long harm. 22,400 trees and lianas belonging to more than 240 species with a minimum dbh of $1 \mathrm{~cm}$ have been censed and mapped in a 6-hectarplot area surrounding the crane (STRI, 2013). 


\section{Maryland forest}

The Maryland forest is located at $11 \mathrm{~m}$ above sea level at the Smithsonian Environmental Research Center (SERC) in Edgewater, Maryland (38 53' 20"N, 76³3'32"W) $(3,4)$. Mean annual rainfall is $1080 \mathrm{~mm}$ and mean annual temperature is $13.2^{\circ} \mathrm{C}$. The site is dominated by mature secondary temperate deciduous forest ("tulip-poplar association" type), which is 120 years old, and it is bisected by a floodplain forest (which was not sampled for this study). The canopy is $30-40 \mathrm{~m}$ high, and the forest is dominated by the species Liriodedron tupilifera (Magnoliaceae), Quercus ssp. (Fagaceae), Fagus grandifolia (Fagaceae), Carya ssp. (Juglandaceae), Acer rubrum (Sapindaceae), Nyssa sylvatica (Cornaceae), Carpinus caroliniana (Betulaceae), Lindera benzoin (Lauraceae), and Asimina triloba (Annonaceae) (STRI 2013, SERC, 2013). Census data about this plot are not publicly available.

\section{METHODS}

\section{Leaf sampling}

In this study, only mature leaves were collected in order to reduce the possible bias in vein density estimate due to different developmental stages of the leaves. Sampling took place in two tropical primary rainforests in Panama and in a temperate secondary deciduous forest in Maryland.

\section{Panama samples}

Leaf sampling in Panama was carried out between January and March 2011. In both Panama forests, canopy leaves were collected by hand from the top of the tree crown (full sun leaves) using a canopy crane. A gondola (metal basket) is attached to the crane allowing sampling in different locations and heights within the forest. The crane sampling method presents several advantages, notably safe, easy and non-destructive access to the upper canopy. The maneuvers of the crane were coordinated with the crane operator through a walkie-talkie. Understorey leaves were collected at breast height or at any height reachable by hand.

119 canopy leaves (form 44 plants belonging to 30 species, 15 of which are trees, 10 lianas, 4 vines, 1 shrub, and 1 hemiepiphyte) and 39 understorey leaves (from 17 plants belonging to 7 species, 5 of which are trees, 2 lianas, and 1 shrub) were collected in PNM. 119 canopy leaves (from 46 plants belonging to 49 species, 30 of which are trees, 14 lianas, 3 hemiepiphyte, and 1 shrub), and 39 understorey leaves (from 23 plants belonging to 16 species, 12 of which are trees, 3 lianas, and 1 shrub) were collected in FTS. Because canopy tree species 
tend to be sun-demanding species and are more abundant in the canopy, whereas understorey tree species tend to be shade adapted and more abundant in the understorey, only 15 species of the 83 collected were sampled in both strata. At least 3 leaves per individual and 1 to 3 individuals per species were sampled in both sites for $D_{V}$ analysis. In order to keep the leaves hydrated, they were stored in a cooler and/or in a refrigerator before the clearing/staining process.

\section{Maryland samples}

Maryland leaf sampling was carried out in June 2012 over a period of 5 days. Understorey leaves in Maryland were collected following the same protocol used in Panama. As there is no crane on the site, I developed alternative methods for canopy leaf sampling. Leaves at the top of the crown of 5 tree species were reached from a meteorological tower and using a cherry picker. 10 species were collected using a new technique consisting of directing a balloon filled with helium and attached to a rope equipped with sharp blades. Pulling and relaxing the rope caused the blades to cut small branches or leaf fragments from the tree crown, which were picked up once they reached the forest floor. As previously done in Panama, at least 3 leaves per individual and 1 to 3 individuals per species were sampled, except for some canopy species for which the lack of time and the lack of precision of the new "balloon technique" did not allow an exhaustive sampling. 48 trees were sampled. A total of 137 canopy leaves belonging to 15 species (13 trees, and 1 woody vine) and 127 understorey leaves belonging to 19 species (12 trees, 6 shrubs, and 1 woody vine) were sampled for $D_{V}$ analysis. Sampled leaves were stored in a cooler and/or in a refrigerator in order to keep them hydrated.

\section{Leaf litter samples}

Leaf litter sampling was carried out in Parque Natural Metropolitano in July 2012. An area of $1 \times 1 \mathrm{~m}^{2}$ was chosen randomly in the forest. All the leaves covering the surface of the area as well as those deposited down to $2 \mathrm{~cm}$ of depth in the sediment were collected. The sampling surface chosen is similar to that used for sampling fossil floras. 173 leaves well enough preserved to allow morphotype classification were used for the study. 18 different morphotypes were identified. Samples were stored in a refrigerator to avoid putrefaction.

\section{Laboratory protocol for leaf clearing, staining, and photographing}

A $2 \mathrm{~cm}^{2}$ section of leaf lamina was excised from each sample, cleared, stained, and photographed for vein density measurements. Although in temperate environments some 
authors have not found significant differences in vein density across the blade of the same leaf (Uhl \& Mosbrugger, 1999), others have observed a significant change in vein density across the blade of mature leaves from the top of the canopy (Zwieniecki et al., 2004); for modern samples, in order to avoid any bias, leaf fragments were all cut from the same site on the blade. Furthermore, major veins were avoided because of their bigger thickness compared to other orders of veins. This was not always possible for litter sample due to the fragmented preservation of the leaves. For modern samples, three fragments (from three leaves of each tree) were stored in a $50 \mathrm{~mL}$ beaker where they were treated with around $25 \mathrm{ml}$ of $10 \% \mathrm{NaOH}$ for clearing. All the Panama litter samples (divided in morphotypes) were stored in $50 \mathrm{~mL}$ beakers and treated with around $35 \mathrm{~mL}$ of $10 \% \mathrm{NaOH}$ for clearing. For modern species, the clearing time varied between species, depending on their leaf thickness and tannin content, and between sites ( 3 weeks to 2 months for Panama leaves, 3 to 10 days for Maryland leaves) because tropical leaves tended to be thicker and to have higher tannin content (personal observation). Therefore, when required (high thickness and/or tannin content), the $\mathrm{NaOH}$ solution was changed. For Panama litter samples the clearing time was between 2 and 3 weeks, and when required (high thickness and/or tannin content), the $\mathrm{NaOH}$ solution was changed. Subsequently, leaves where rinsed with distilled water 2 to 3 times. After a dehydration series with 50\%,75\%,95\%, and 100\% ethanol ( 1 minute for each concentration), leaves were stained in a Safranin (2\%) - Ethanol (50\%) solution for 1 hour minimum. The duration of the dehydration process was sometimes lengthened (with a supplementary Ethanol 100\% step) because this facilitated further clearing of the specimens. The specimens were observed on a Petri dish using a stereoscope equipped with a camera (Nikon DXN1200C for the Panama samples; Leica DFC 480 for the Maryland samples), at a magnification of 20x. At least 3 photos were taken for each leaf fragment. Panama modern samples were processed and photographed at Carlos Jaramillo's lab at the CTPA (Center for Tropical Paleoecology and Archaeology) of the STRI (Smithsonian Tropical Research Institute) in Panama. Maryland samples were processed and photographed using the facilities of Kevin Boyce's laboratory at the University of Chicago (IL).

\section{Leaf vein density measurements}

Leaf vein density was estimated using a 2-dimensional method based on the measurement of the total vein length per unit leaf area. All the veins present in a known area (a) were drawn by hand and their total length (L) was measured using digital image analysis (Image J; National 
Institute of Health, Bethesda, MD, USA) (fig. 2). Then, the leaf vein density $\left(D_{V}\right)$ of each leaf was simply calculated as follow:

$$
D_{V}=\mathrm{L} / \mathrm{a}
$$

The area measured was around $10 \mathrm{~mm}^{2}$ for Panama samples and $4 \mathrm{~mm}^{2}$ for Maryland and litter samples. The choice of a smaller area for Panama-litter and Maryland samples is consistent with other studies published in the literature (Boyce et al., 2009) and reduced the duration of the measurement phase by more than half the original time (15-30 minutes versus 30 minutes-1 hour per photo). It is important to note that this manual $D_{\mathrm{v}}$ estimation technique is extremely timeconsuming. Therefore, reducing the time spent on measurements was considered a crucial point for the feasibility of this project. The effects of human error and variable measured areas on $D_{\mathrm{v}}$ estimations were also tested. The test showed that varying the area measured did not affect $D_{\mathrm{v}}$ estimation. Nonetheless, human error may occur for at especially at high $D_{\mathrm{v}}$, and when the researcher has little experience with $D_{\mathrm{v}}$ measurement (although results are consistent from measurement to measurement) (SI table 1 and figure 3). 1 to 3 measurements were performed for each leaf, and averaged in order to obtain a single mean value. Then, the $D_{\mathrm{v}}$ for each species was calculated averaging the values obtained for the single leaves.

\section{Statistical analyses}

$D_{\mathrm{v}}$ values of canopy and understory leaves were compared among different ecological strategies and sites. $D_{\mathrm{v}}$ of the PNM standing forest was compared to the PNM leaf litter assemblage as well. The PNM litter was then compared to fossil data selected from Feild et al.'s (2011) Cretaceous-Paleocene dataset. These data include only morphotypes coming from a single formation per each time period. In order to test the effects of phylogeny on $D_{\mathrm{v}}$, I also compared $D_{\mathrm{v}}$ among different large clades and between early- and late-diverging angiosperms. Wilcoxon rank-sum tests conducted in R 3.0.0 (R Development Core Team, 2013) were used for all comparisons because the data were not normally distributed (Shapiro-Wilk Normality test). All life forms together (trees, shrubs, hemiepiphyte, lianas, vines, and woody vines) were included in my analyses.

\section{RESULTS}

Vein density is higher in the canopy than in the understory in PNM (average $D_{\mathrm{v}}=$ $13.29 \pm 4.57$ versus $8.98 \pm 2.75 \mathrm{~mm} / \mathrm{mm}^{2}$ ), FTS (average $D_{\mathrm{v}}=10.41 \pm 3.13$ versus $5.98 \pm 1.63$ $\mathrm{mm} / \mathrm{mm}^{2}$ ), and SERC (average $D_{\mathrm{v}}=10.87 \pm 2.49$ versus $6.07 \pm 1.62 \mathrm{~mm} / \mathrm{mm}^{2}$ ) forests $(p<0.01$ ) 
(fig.2). However the three sites present some differences: (1) canopy $D_{\mathrm{v}}$ is not significantly different between FTS and SERC ( $p=0.362)$, and between PNM and SERC $(\mathrm{p}=0.069)$ but it is different between FTS and PNM ( $p<0.01)$; (2) understorey $D_{\mathrm{v}}$ is not significantly different between FTS and SERC ( $p=0.935)$ but it is significantly different between PNM and the two other sites $(p<0.05)$; (3) when putting canopy and understorey data together, the overall $D_{\mathrm{v}}$ distribution of PNM (average $D_{\mathrm{v}}=12.47 \pm 4.58$ ) significantly differs from that of FTS (average $\left.D_{\mathrm{v}}=9.32 \pm 3.41\right)$ and SERC (average $\left.D_{\mathrm{v}}=8.19 \pm 3.15\right)(p<0.01)$, whereas SERC and FTS $D_{\mathrm{v}}$ distributions are not significantly different $(p=0.106)$. Furthermore, the $D_{\mathrm{v}}$ curve of the PNM litter (average $D_{\mathrm{v}}=10.66 \pm 5.66 \mathrm{~mm} / \mathrm{mm}^{2}$ ) assemblage is not significantly different from that of the PNM standing forest (average $\left.D_{\mathrm{v}}=12.47 \div 4.58 \mathrm{~mm} / \mathrm{mm}^{2}\right)(p=0.071)$ and it is more similar to the PNM understorey $(\mathrm{p}=0.057)$ than to the PNM canopy $(\mathrm{p}<0.05)($ fig. $2 \mathrm{C})$.

$D_{v}$ of canopy leaves is higher than $D_{v}$ of understorey leaves regardless of being either a sundemanding or shade-tolerant tree (Table 1). Lumping the data from all three sites, sunestablished and shade-tolerant species have similar average canopy $D_{v}$ values and similar average understorey $D_{v}$ values. Average $D_{\mathrm{v}}$ values and $p$-values per site, ecology, and forest strata are reported in Table 1; the small sample size for some of these categories did not always allow me to test the hypothesis of a $D_{\mathrm{v}}$ difference between species ecologies at the site level.

$D_{v}$ varies among clades, but in all clades canopy Dv values are significantly higher than understory Dv values (fig. 3). Although $D_{\mathrm{v}}$ averages for early- and late-diverging angiosperms are similar (11.1 and $11.7 \mathrm{~mm} / \mathrm{mm}^{2}$, respectively), the range for late-diverging angiosperms ( $\max$ $\left.=27.2 \mathrm{~mm} / \mathrm{mm}^{2}, \min =5.1 \mathrm{~mm} / \mathrm{mm}^{2}\right)$ is higher than that of early-diverging angiosperms $(\max =$ $13.9 \mathrm{~mm} / \mathrm{mm}^{2}, \min =8.4 \mathrm{~mm} / \mathrm{mm}^{2}$ ).

The PNM litter $D_{\mathrm{v}}$ is significantly different $(p<0.05)$ from all fossil assemblages except for the Paleocene and Masstrichtian ones (fig. 4).

\section{DISCUSSION}

\section{Canopy versus understory trees}

Vein density tends to be higher in the canopy independent of site, life form and ecology, suggesting that the location of the leaf within the forest is the main factor in determining $D_{\mathrm{v}}$. Light irradiance may be one of the major factor driving $D_{\mathrm{v}}$, as it is for many other leaf traits (Denslow, 1987; Rijkers et al., 2000), although other parameters such as the height of trees, relative humidity, and temperature may also play a role. Because all these factors and tree height 
are strictly associated, my experimental design does not allow us to isolate these variables. However, a possible influence of all these factors at the same time does not affect my hypothesis that $D_{\mathrm{v}}$ is higher in the canopy than in the understorey, according to differential transpiration and metabolic needs at different forest strata. Furthermore this result suggests that high vein density is a unique character of emergent canopy trees. Hence, this trait can likely be used in the fossil record to characterize past ecosystems where angiosperm trees were a dominant component of the forest canopy.

\section{Differences between sites}

The difference in $D_{\mathrm{v}}$ distribution between sites is likely the effect of two interplaying factors: (1) a sampling bias - the ratio of canopy to understorey samples varies between PNM ( 4.3), FTS $(\sim 3)$, and SERC ( 0.7) - and (2) a significant difference in canopy and understorey average $D_{\mathrm{v}}$ among sites. The high canopy:understorey sample ratio at PNM compared to FTS and SERC may explain why PNM $D_{\mathrm{v}}$ distribution tends toward the high-values side of the $D_{\mathrm{v}}$ axis, and differs significantly from that of FTS and SERC. Despite these differences, higher $D_{\mathrm{v}}$ values in the forest canopy than in the understorey characterize all three study sites, reflecting closed-canopy environments dominated by angiosperm trees.

\section{Sun-established versus shade-tolerant species}

Different levels of light irradiation are thought to be the main control on variations in physiological traits throughout the forest. However, if light was the only control on $D_{\mathrm{v}}$, I would expect sun-established trees to have significantly higher $D_{\mathrm{v}}$ than shade-tolerant species. The absence of an influence of tree ecological strategy on $D_{\mathrm{v}}$, together with the fact that vein density is higher in the canopy than in the understorey in both sun-established and shade-tolerant species, indicate that the placement (not only light availability) of the leaf within the forest is the main driver of vein density variations. I suggest that other factors, such as tree height, also play an important role in modulating plant physiological adaptation including vein density. Rijkers et al. (2000) observed a positive relationship between tree height, leaf mass per area (LMA), and light-saturated rate of photosynthesis per unit area $\left(A_{\max } /\right.$ area). Cavaleri et al. (2010) related the LMA vertical gradient within a forest canopy to tree height, and hypothesized a direct effect of gravity on leaf water potential and turgor pressure, which in turn would affect LMA. I suggest that this hydraulic mechanism has similar effects on venation density. 


\section{Early-diverging versus late-diverging angiosperms}

$D_{\mathrm{v}}$ varies largely among plant taxa. The higher range of $D_{\mathrm{v}}$ variation in late-diverging angiosperms suggests a higher plasticity, allowing them to explore different ecological niches within an ecosystem. The smaller range of $D_{\mathrm{v}}$ variation and the paucity of high $D_{v}$ values in early-diverging angiosperms is consistent with Boyce et al.'s (2009) and Boyce and Leslies' (2012) observations of high vein density as a unique character of late-diverging angiosperms. Furthermore, the presence of high $D_{\mathrm{v}}$ values in late-diverging angiosperms at different taxonomic positions is in agreement with the Boyce et al. (2009) interpretation that increases in $D_{\mathrm{v}}$ occurred multiple times during angiosperms' diversification.

\section{Leaf litter}

The PNM litter assemblage does not significantly differ from the samples collected from living trees. Most leaves whose provenance (canopy or understorey) is not doubtful come from the canopy, confirming the hypothesis that canopy leaves are overrepresented in the fossil record due to their higher production, as traditionally assumed (Stebbins, 1965; Burnham et al., 1992; Burnham, 1994). However, the data also indicate that understorey leaves contribute to the litter assemblage in a visible manner and that, in general, a litter assemblage is composed of leaves coming from different strata of the forest. This suggests that fossil flora assemblages may be more representative of an ecosystem that previously thought.

\section{Vein density and the fossil record}

The presence of the same $D_{\mathrm{v}}$ trend in both tropical and temperate regions suggests that this trait varies independent of climate, and it mainly reflects the occurrence of a highly competitive ecosystem where different species cohabit in different forest strata by modulating their physiological traits, including $D_{\mathrm{v}}$. Hence, low $D_{\mathrm{v}}$ is associated with lower metabolic rates and transpiration in the understorey, whereas high $D_{\mathrm{v}}$ allows higher transpiration in the upper canopy. Consequently, $D_{\mathrm{v}}$ can be used in the fossil record to investigate the ecological strategies

of angiosperms even in those time periods when climate is not well constrained. The vein density curve derived from the histograms of PNM litter assemblage is not significantly different from those obtained for the Paleocene and Maastrichtian floras, suggesting that the emergence of angiosperms as forest canopy members took place at that time. In fact, high vein density values only evolved by the end of the Masstrichtian, (Feild et al., 2011); angiosperms metabolic capabilities were limited by lower transpiration and assimilation rates and as a consequence they 
were unlikely able to attain and dominate the upper strata of the forest. The vein density curve of the Maastrichtian is not significantly different from that of PNM. Nevertheless, it lacks the lowest and highest modern $D_{\mathrm{v}}$ values, resulting in a smaller $D_{\mathrm{v}}$ value range for the Masstrichtian ( $\left.7.33-15.42 \mathrm{~mm} / \mathrm{mm}^{2}\right)$ compared to the modern PNM litter assemblage $\left(1.11-25.3 \mathrm{~mm} / \mathrm{mm}^{2}\right)$. Additional data are needed to verify whether this observation is the result of a small sample size or it reflects a different type of ecosystem, where angiosperms had not yet attained all forest layers.

\section{CONCLUSION}

Vein density variation within a modern angiosperm-dominated forest is mainly driven by the forest strata in which the leaf is located, and it is independent of plant ecological strategy and site. Different forest strata correspond to variable amounts of available light and different tree height, as well as other variable parameters like temperature, humidity, and $\mathrm{CO}_{2}$ concentration. I suggest that tree height, not only light availability, is a major factor modulating $D_{\mathrm{v}}$ variation

through forest strata. Because differences in $D_{\mathrm{v}}$ average values between sites are most likely due to a sampling bias rather than to any environmental or climatic differences, $D_{\mathrm{v}}$ can be used as a proxy to trace the emergence of angiosperm trees in the forest canopy in the fossil record even for those time periods whose climatic variables are uncertain.

Although leaves in a litter assemblage are more likely to come from the canopy than from the understorey, understorey leaves are more represented than previously thought. Assuming that a litter assemblage is similar in composition to a fossil leaf assemblage, I propose that fossil floras are representative of the $D_{\mathrm{v}}$ variation in the standing forest. Of the 8 fossil leaf assemblages analyzed in this study, the Paleocene flora has the most similar $\mathrm{D}_{\mathrm{v}}$ density curve to modern tropical forest litter. Although the Maastrichtian flora is not significantly different from the tropical litter assemblage, more samples are needed for the Masstrichtian to strongly support any interpretation of the data. In conclusion, results suggest the occurrence of angiosperm as forest canopy members at least $58 \mathrm{Ma}$. 


\section{Section 2: The Mush Valley paleoflora: a preliminary case study of vein density as a proxy for canopy closure}

\section{INTRODUCTION}

The two main objectives of this study were: 1) to explore the potential of fossil leaf cuticles for vein density measurements, and 2) to test vein density as a proxy for forest canopy coverage in the fossil record. The Mush Valley flora is an excellent candidate for this work because of its optimal state of preservation and because, as suggested by previous taxonomical studies, it represents a late stage successional forest, where trees were presumably tall enough to create a closed-canopy environment. In fact, taxa typically found in modern forest gaps and forest understorey are present in the Mush Valley flora (Currano et al. 2011; Pan, 2012; Pan et al., in prep).

\section{SITE OF THE STUDY}

The fossils used for this study come from Early Miocene sediments located in the Mush Valley, Ethiopia, approximately $160 \mathrm{~km}$ northeast of Addis Ababa in Debre Birhan Woreda. The sediments are mainly carbonaceous shales and mudstones where fossils are abundant and extremely well preserved. The site was interpreted as a lacustrine deposit (Pan et al., 2012). The age of the site is $\sim 21.7 \mathrm{Ma}$ (Pan et al., 2012), and it has been constrained using ${ }^{239} \mathrm{U} /{ }^{206} \mathrm{~Pb}$ isotopes from zircons present in an ash layer.

\section{METHODS}

Thirty cuticle samples were selected for vein density measurements. Cuticle fragments ( $0.5-1 \mathrm{~mm}^{2}$ ) were taken from each sample and soaked in a $0.1 \mathrm{M}$ solution of tetrasodium pyrophosphate decahydrate $\left(\mathrm{Na}_{4} \mathrm{P}_{2} \mathrm{O}_{7}\right)$ (Bates et al., 1978) for a week in order to facilitate the separation of the cuticles from the rock matrix. Each cuticle was then put in a $48 \%$ HF solution to dissolve the silicate rock matrix (Barclay, 2011). Rock matrix dissolution generally took around 1 month. After isolation, the cuticles were stored in a slightly acidic distilled water solution to avoid fungal contamination. Venation density was measurable on 17 samples, belonging to 12 morphotypes. The area measured varies depending on the sample preservation and its available measurable surface (Table 2). Many treated samples were excluded from the analysis because they were too dark and, despite being present, veins were hardly visible. In addition several morphotypes had a very thin cuticle, which disintegrated during treatment. 
Measured samples were plotted on a histogram and a density curve of $D_{\mathrm{v}}$ was obtained and compared to that of the PNM litter using R3.0.0. (R Development Core Team, 2013). A subsample of 12 morphotypes was extracted randomly 10,000 times from PNM litter using a bootstrap with replacement, and the histogram obtained was plotted together with the average Dv of Mush Valley flora.

\section{RESULTS}

Average vein density is $15.82 \pm 4.54 \mathrm{~mm} / \mathrm{mm}^{2}$, with a minimum of $9.85 \mathrm{~mm} / \mathrm{mm}^{2}$ and a maximum of $24.77 \mathrm{~mm} / \mathrm{mm}^{2}$. Mush Valley $D_{\mathrm{v}}$ distribution is significantly different from that of PNM litter $(p<0.01)$ (fig. 5A). PNM litter average and minimum $D_{\mathrm{v}}\left(10.66 \mathrm{~mm} / \mathrm{mm}^{2}\right.$ and 1.11 $\mathrm{mm} / \mathrm{mm}^{2}$ ) are lower than that of Mush Valley $\left(15.82 \mathrm{~mm} / \mathrm{mm}^{2}\right.$ and $\left.9.85 \mathrm{~mm} / \mathrm{mm}^{2}\right)$, whereas maximum $D_{\mathrm{v}}$ is very similar $\left(25.29 \mathrm{~mm} / \mathrm{mm}^{2}\right.$ for PNM litter, and $24.77 \mathrm{~mm} / \mathrm{mm}^{2}$ for Mush Valley). $11.56 \%$ of the PNM litter subsamples extracted with the bootstrap have an average equal or higher than that of Mush Valley. All other subsamples' (88.44\%) averages are below that of Mush valley flora (fig. 5B).

\section{DISCUSSION}

Differences between the PNM litter assemblage and the Mush Valley fossil assemblage may be either the result of the low sample size of Mush Valley flora or they may be due to environmental differences between PNM modern tropical forest and Mush Valley paleoflora. Previous studies suggested that the Mush Valley flora represents a secondary succession forest, but also provided evidence for forest gaps and disturbed habitats (Currano et al. 2011; Pan, 2012; Pan et al., in prep). Assuming that the hypothesis that light is the main control on vein density is true, then gaps may account for the higher $D_{\mathrm{v}}$ values observed in the Mush Valley flora. Nonetheless, assuming that the main factor controlling $D_{\mathrm{v}}$ is tree height, high vein density values may reflect a forest dominated by relatively tall trees, plausibly creating dense canopy coverage. Hence, the absence of understorey-like $D_{\mathrm{v}}$ values may be simply due to a non-exhaustive sampling.

\section{CONCLUSION}

A more extensive sampling effort is required in order to make more definitive conclusions. Methods of cuticle treatment need to be improved. After the isolation treatment, cuticles could be treated using modern leaf clearing procedures. In order to eliminate the darkcolored material surrounding the veins, cuticles should be put into a $\mathrm{NaOH}$ solution for a few 
hours/days. $\mathrm{NaOH}$ concentration should be low enough to avoid cuticle disintegration. Eventually, if the clearing is successful, cuticles could be stained using a Safranine solution, as done with modern leaves for morphological observation. Hence, more experimentation on clearing and staining methods is needed to determine precisely $\mathrm{NaOH}$ concentration, cuticle clearing time, and staining procedures. 


\section{REFERENCES}

Barclay, Richard Shern. "Testing The Driving Mechanisms For Ocean Anoxic Event 2 (94Ma) Using $\mathrm{pCO}_{2}$ Estimates And Carbon Isotopes Derived From Fossil Plant Material In The Dakota Formation Of Southwestern Utah". Ph.D. diss., Northwestern University, 2011. ProQuest: 3456521.

Bates, C.D., Coxon, P., \& Gibbard, P.L., 1978, A new methods for the preparation of clay-rich sediment samples for palynological investigation: New Phytologist, v. 81, p. 459-463.

Beerling, D.J., and Franks, P.J., 2010, The hidden cost of transpiration: Nature, v. 464, p. 495496.

Boyce, C.K., Brodribb, T.J., Feild, T.S., and Zwieniecki, M.A., 2009, Angiosperm leaf vein evolution was physiologically and environmentally transformative: Proceedings of the Royal Society B-Biological Sciences, v. 276, p. 1771-1776.

Boyce, C.K., 2009, Seeing the forest with the leaves - clues to canopy placement from leaf fossil size and venation characteristics: Geobiology, v. 7, p. 192-199.

Boyce, C.K., and Leslie, A.B., 2012, The Paleontological Context of Angiosperm Vegetative Evolution: International Journal of Plant Sciences, v. 173, p. 561-568.

Brodribb, T.J., Feild, T.S., and Jordan, G.J., 2007, Leaf maximum photosynthetic rate and venation are linked by hydraulics: Plant Physiology, v. 144, p. 1890-1898.

Burnham, R.J., Wing, S.L., and Parker, G.G., 1992, The Reflection of Deciduous Forest Communities in Leaf Litter - Implications for Autochthonous Litter Assemblages from the Fossil Record: Paleobiology, v. 18, p. 30-49.

Burnham, R.J., 1994, Patterns in Tropical Leaf-litter and Implications for Angiosperm Paleobotany: Review of Palaeobotany and Palynology, v. 81, p. 99-113.

Burnham, R.J., and Johnson, K.R., 2004, South American palaeobotany and the origins of neotropical rainforests: Philosophical Transactions of the Royal Society of London Series B-Biological Sciences, v. 359, p. 1595-1610.

Brown, M.J., and Parker, G.G., 1994, Canopy Light Transmittance in a Chronosequence of Mixed-Species Deciduous Forests: Canadian Journal of Forest Research-Revue, v. 24, p. 1694-1703.

Campanello, P.I., Gatti, M.G., and Goldstein, G., 2008, Coordination between water-transport efficiency and photosynthetic capacity in canopy tree species at different growth 
irradiances: Tree Physiology, v. 28, p. 85-94.

Cavaleri, M.A., Oberbauer, S.F., Clark, D.B., Clark, D.A., and Ryan, M.G., 2010, Height is more important than light in determining leaf morphology in a tropical forest: Ecology, v. 91, p. $1730-1739$.

Crane, P.R., Friis, E.M., and Pedersen, K.R., 1995, The origin and early diversification of angiosperms: Nature, v. 374, p. 27-33.

Currano, E.D., Jacobs, B.F., Pan, A.D., and Tabor, N.J., 2011, Inferring ecological disturbance in the fossil record: A case study from the late Oligocene of Ethiopia: Palaeogeography Palaeoclimatology Palaeoecology, v. 309, p. 242-252.

Davis, C.C., Webb, C.O., Wurdack, K.J., Jaramillo, C.A., and Donoghue, M.J., 2005, Explosive radiation of malpighiales supports a mid-Cretaceous origin of modern tropical rain forests: American Naturalist, v. 165, p. E36-E65.

de Boer, H.J., Eppinga, M.B., Wassen, M.J., and Dekker, S.C., 2012, A critical transition in leaf evolution facilitated the Cretaceous angiosperm revolution: Nature communications, v. 3, p. $12-21$.

Denslow, J.S., 1987, Tropical Rainforest Gaps and Tree Species Diversity: Annual Review of Ecology and Systematics, v. 18, p. 431-451.

Feild, T.S., Brodribb, T.J., Iglesias, A., Chatelet, D.S., Baresch, A., Upchurch, G.R., Jr., Gomez, B., Mohr, B.A.R., Coiffard, C., Kvacek, J., and Jaramillo, C., 2011, Fossil evidence for Cretaceous escalation in angiosperm leaf vein evolution: Proceedings of the National Academy of Sciences of the United States of America, v. 108, p. 8363-8366.

McKown, A.D., Cochard, H., and Sack, L., 2010, Decoding Leaf Hydraulics with a Spatially Explicit Model: Principles of Venation Architecture and Implications for Its Evolution: American Naturalist, v. 175, p. 447-460.

Meinzer, F.C., Bond, B.J., and Karanian, J.A., 2008, Biophysical constraints on leaf expansion in a tall conifer: Tree Physiology, v. 28, p. 197-206.

Mulkey, S.S., Kitajima, K., and Wright, S.J., 1996, Plant physiological ecology of tropical forest canopies: Trends in Ecology \& Evolution, v. 11, p. 408-412.

Noblin, X., Mahadevan, L., Coomaraswamy, I.A., Weitz, D.A., Holbrook, N.M., and Zwieniecki, M.A., 2008, Optimal vein density in artificial and real leaves: Proceedings of the National Academy of Sciences of the United States of America, v. 105, p. 9140-9144. 
Pan, A.D., Currano, E.D., Jacobs, B.F., Feseha, M., Tabor, N., and Herendeen, P.S., 2012, Fossil Newtonia (Fabaceae: Mimoseae) Seeds from the Early Miocene (22-21 ma) Mush Valley in Ethiopia: International Journal of Plant Sciences, v. 173, p. 290-296.

Pan, A.D., Jacobs B.F., and Currano' E.D., in prep. Dioscoreaceae fossils from the late Oligocene and early Miocene of Ethiopia.

Panditharathna, P.A.K.A.K., Singhakumara, B.M.P., Griscom, H.P., and Ashton, M.S., 2008, Change in leaf structure in relation to crown position and size class for tree species within a Sri Lankan tropical rain forest: Botany, v. 86, p. 633-640.

R Core Team (2013). R: A language and environment for statistical computing. R Foundation for Statistical Computing, Vienna, Austria.

Rijkers, T., Pons, T.L., and Bongers, F., 2000, The effect of tree height and light availability on photosynthetic leaf traits of four neotropical species differing in shade tolerance: Functional Ecology, v. 14, p. 77-86.

Rueger, N., Huth, A., Hubbell, S.P., and Condit, R., 2009, Response of recruitment to light availability across a tropical lowland rain forest community: Journal of Ecology, v. 97, p. 1360-1368.

Sack, L., Tyree, M.T., and Holbrook, N.M., 2005, Leaf hydraulic architecture correlates with regeneration irradiance in tropical rainforest trees: New Phytologist, v. 167, p. 403-413.

Sack, L., and Frole, K., 2006, Leaf structural diversity is related to hydraulic capacity in tropical rain forest trees: Ecology, v. 87, p. 483-491.

SERC, 2013, Visiting SERC, Eastern Deciduous Forest: http://www.serc.si.edu/visiting/about/decid_forest.aspx (December 2012).

Stebbins, G.L., 1965, The probable growth habit of the earliest flowering plants: Annuals of the Missouri Botanical Garden, v.53, p. 457-468.

STRI 2013, Institutional background and description of crane sites:

http://www.stri.si.edu/english/research/facilities/terrestrial/cranes/research_info.ph (December 2012).

STRI 2013, Cranes and sites specifications:

http://www.stri.si.edu/english/research/facilities/terrestrial/cranes/cranes_and_sites.php (December 2012). 
STRI, 2013, SERC: Smithsonian Environmental Research Center:

http://www.ctfs.si.edu/site/SERC\%3A+Smithsonian+Environmental+Research+Center (December 2012).

Uhl, D., and Mosbrugger, V., 1999, Leaf venation density as a climate and environmental proxy: a critical review and new data: Palaeogeography Palaeoclimatology Palaeoecology, v. 149, p. 15-26.

USDA Forest Service, Fire Effects Information System, Plant Species Life Form: http://www.fs.fed.us/database/feis/plants/index.html (December 2012).

Wang, H., Moore, M.J., Soltis, P.S., Bell, C.D., Brockington, S.F., Alexandre, R., Davis, C.C., Latvis, M., Manchester, S.R., and Soltis, D.E., 2009, Rosid radiation and the rapid rise of angiosperm-dominated forests: Proceedings of the National Academy of Sciences of the United States of America, v. 106, p. 3853-3858.

Wing, S.L., Herrera, F., Jaramillo, C.A., Gomez-Navarro, C., Wilf, P., and Labandeira, C.C., 2009, Late Paleocene fossils from the Cerrejon Formation, Colombia, are the earliest record of Neotropical rainforest: Proceedings of the National Academy of Sciences of the United States of America, v. 106, p. 18627-18632.

Wing, S.L., Stromberg, C.A.E., Hickey, L.J., Tiver, F., Willis, B., Burnham, R.J., and Behrensmeyer, A.K., 2012, Floral and environmental gradients on a Late Cretaceous landscape: Ecological Monographs, v. 82, p. 23-47.

Yanez-Espinosa, L., Terrazas, T., Lopez-Mata, L., and Valdez-Hernandez, J.I., 2003, Leaf trait variation in three species through canopy strata in a semi-evergreen Neotropical forest: Canadian Journal of Botany-Revue Canadienne De Botanique, v. 81, p. 398-404.

Zwieniecki, M.A., Boyce, C.K., and Holbrook, N.M., 2004, Hydraulic limitations imposed by crown placement determine final size and shape of Quercus rubra L. leaves: Plant Cell and Environment, v. 27, p. 357-365. 


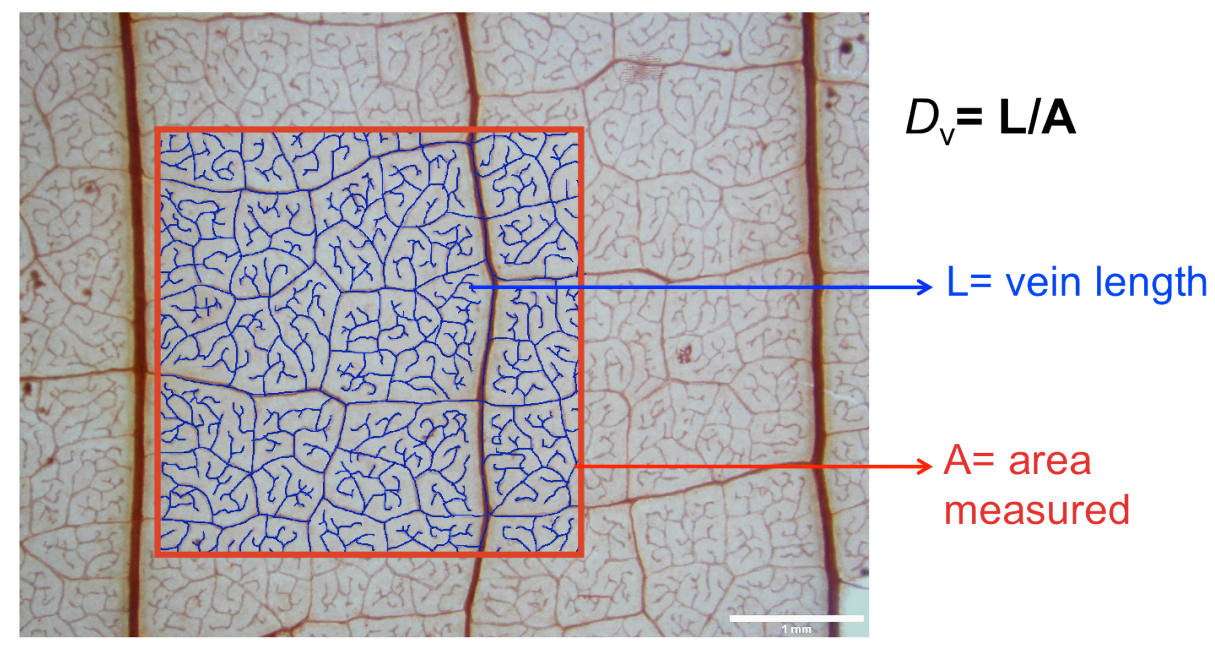

Figure 1: Photo of a leaf of Miconia borealis (Melastomataceae) for vein density estimation. Leaf vein density was calculated by drawing by hand all the veins present in a known area (a, in red). Both total vein length ( $\mathrm{L}$, in blue) and measured area were measured after having been drowned using digital image analysis (Image J; National Institute of Health, Bethesda, MD, USA). Vein density was calculates as $\left(D_{V}\right)=\mathrm{L} / \mathrm{a}$. 

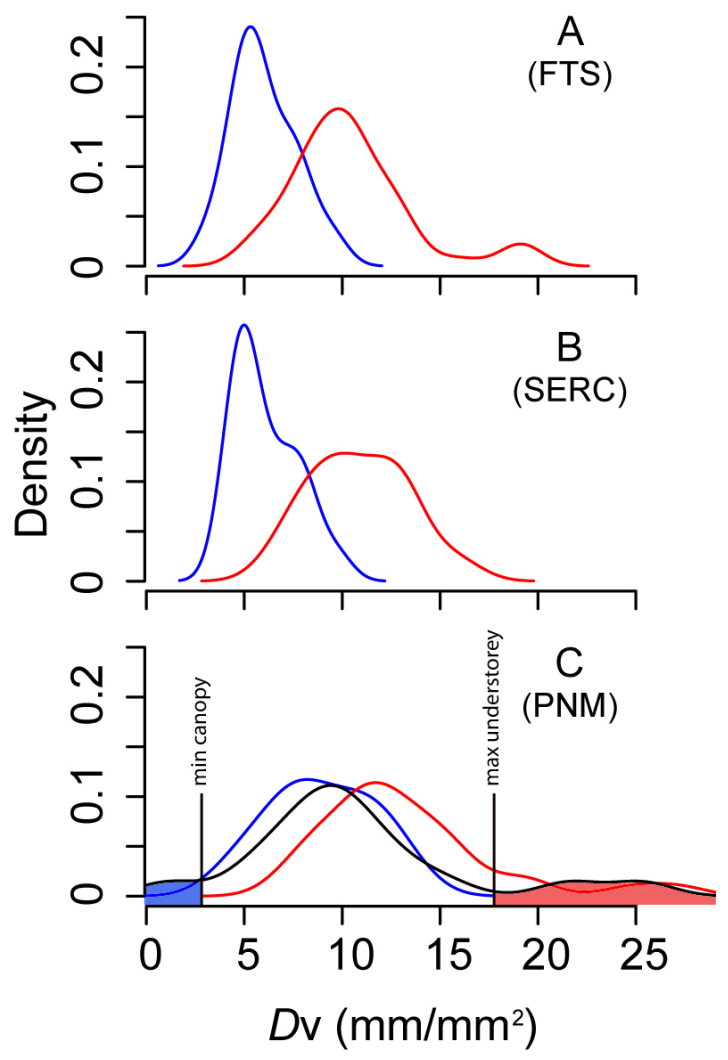

Figure 2. These graphics was obtained using the R function "density" and it represents the probability density function (pdf) or density of the continuous variable $D_{\mathrm{v}}$. The pdf is a function that describes the relative likelihood for the variable $D_{\mathrm{v}}$ to fall within a particular region of an histogram. This probability is given by the integral of this variable's density over the region. The algorithm used by this function disperses the mass of the empirical distribution function over a regular grid of at least 512 points, which represent a compromise between smoothing enough to eliminate insignificant bumps and smoothing too much so that real peaks are eliminated. Then, a fast Fourier transform is used to convolve this approximation with a discretized version of the kernel (a non-parametric test to estimate the probability density function), and a linear approximation is used to evaluate the density at the specified points.

Wilcoxon rank-sum tests on the data show significant differences $(p<0.01)$ between canopy (red) and understorey (blue) in: A. FTS, B. SERC, and C. PNM forests. $D_{\mathrm{v}}$ distribution does not significantly differ between FTS and SERC $(p>0.05)$ but is significantly different between SERC and PNM $(p<0.01)$ and between PNM and FTS $(p<0.01)$. The black line in C represents the litter $D_{\mathrm{v}}$ density curve, which is more similar to PNM understorey $(\mathrm{p}>0.05)$ than to PNM canopy $(\mathrm{p}<0.05)$. Red and blue colored areas under the litter curve correspond to $D_{\mathrm{v}}$ values respectively higher and lower than the maximum understorey and minimum canopy values encountered in PNM.

Canopy samples size (number of species) is 49 for FTS, 10 for SERC, and 30 for PNM. Understorey samples size is 16 for FTS, 19 for SERC, and 7 for PNM for the understorey. 

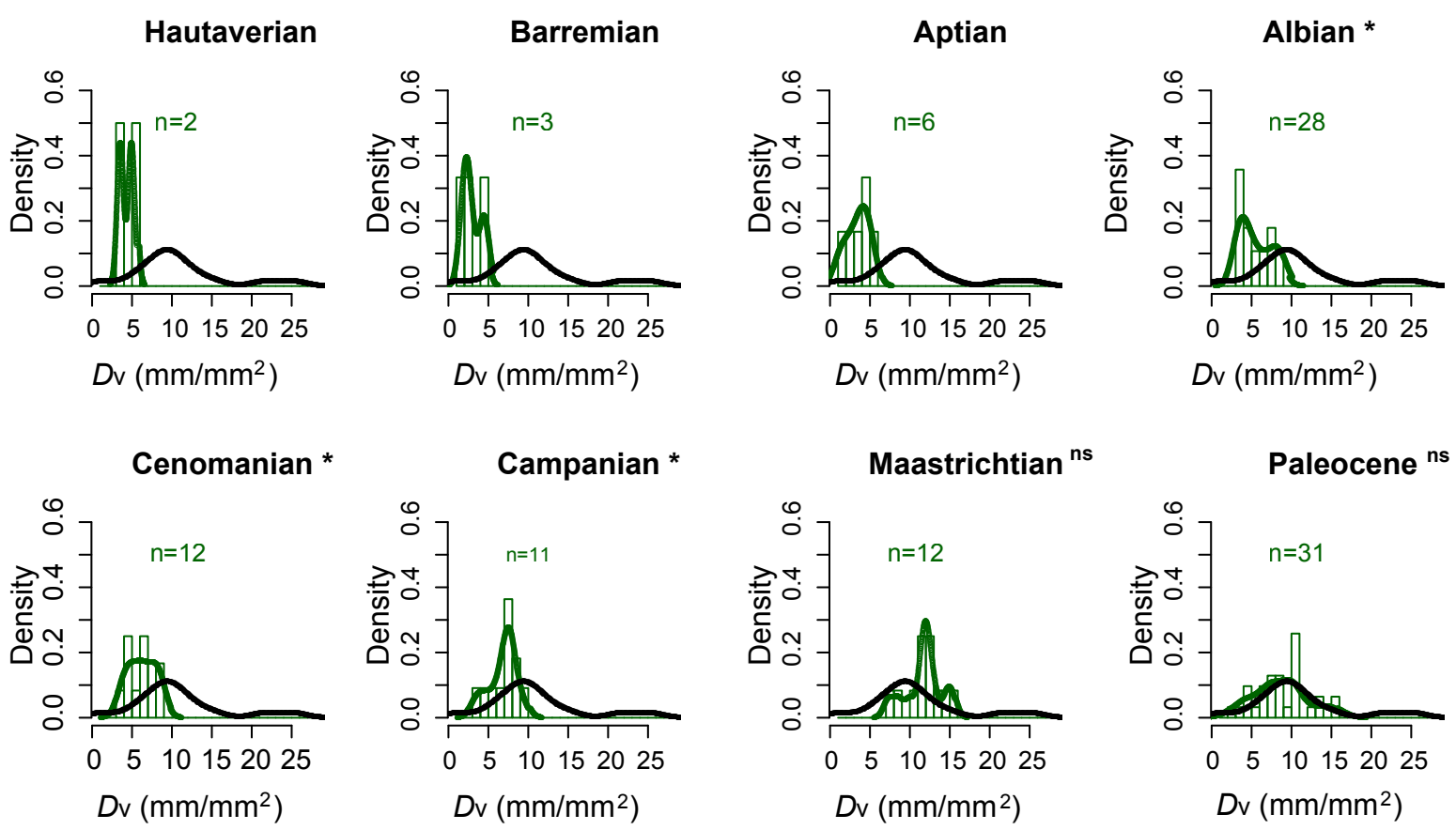

Figure 3. $D_{\mathrm{v}}$ density curves (see figure 2 for more details) of 8 paleofloras (green) compared to the $D_{\mathrm{v}}$ density curve of the PNM litter (in black). $p$-values for Hautaverian, Barremian and Aptian are not provided because of the limited sample size. $p<0.01$ for the Albian $\left(3.99 \times 10^{-5}\right)$, Cenomanian (0.0016), and Campanian (0.013). $\mathrm{p}>0.05$ for the Masstrichtian (0.1134) and the Paleocene $(0.2583)$. ${ }^{*}$ and ${ }^{n s}$ indicate significant and not significant Wilcoxon rank-sum tests. The abbreviation " $n$ " indicates the sample size (number of leaf morphotypes). For PNM litter, $n$ $=19$. Fossil $D_{\mathrm{v}}$ data were selected from Field et al.'s (2011) dataset and include only morphotypes coming from a single formation per each time period (Hautevaerian: Chengzihe Formation, near Jixi, China; Barremian: Las Hoyas locality, La Huérguina Formation, Las Hoyas locality, Iberian Ranges, Spain; Aptian: Crato Formation, Brasil; Albian: Hoisington III, Dakota Formation, KS, USA; Cenomanian: Courtland, Dakota Formation, MN, USA; Campanian: Grunbach Formation, Austria; Maastrichtian: Guadas Formation, Colombia; Paleocene: Cerrejón Formation, Colombia). 

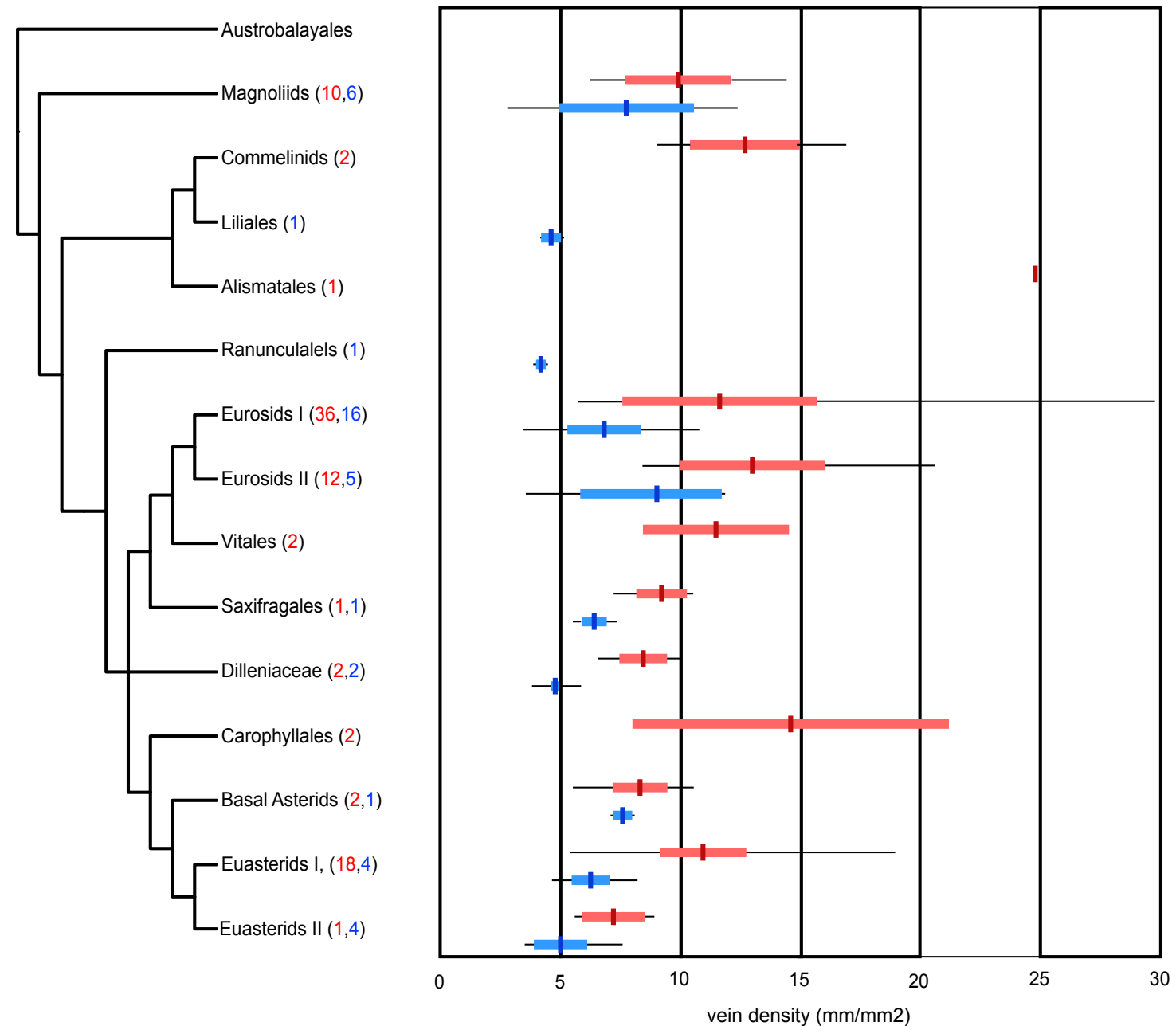

Figure 4. Phylogenetic distribution of leaf vein density. The phylogeny was compiled using all species from this study (Angiosperm Phylogeny Groups, 2009). Group mean (dark red rectangles for canopy values, and dark blue rectangles for understorey values), and standard deviation (lighter rectangles) are provided when sampling is sufficient. Black lines indicate minimum maximum ranges. The number of species corresponding to each value is indicated parenthetically (in red for canopy, and in blue for understorey values). 
A

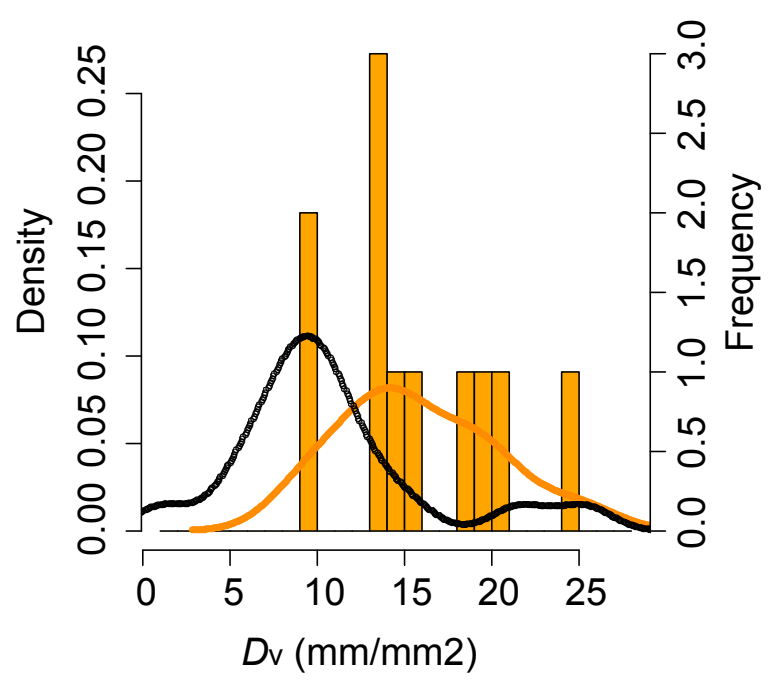

B

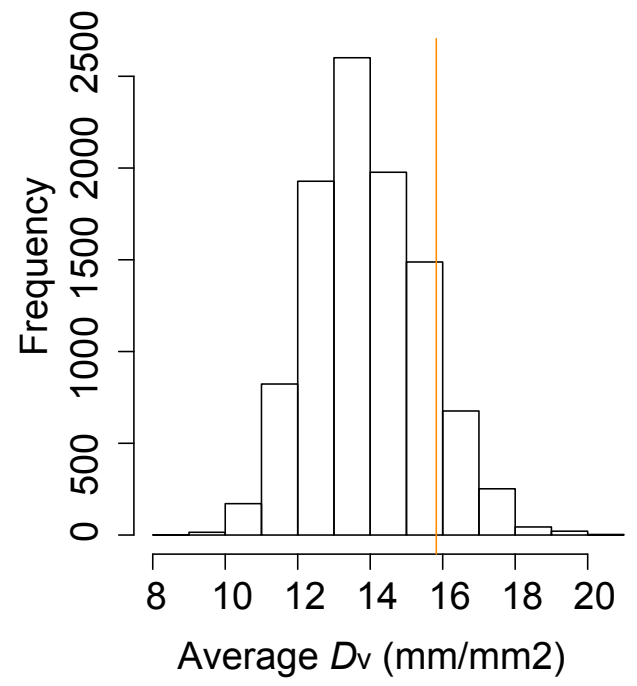

Figure 5. A. $D_{\mathrm{v}}$ density curve and histogram of Mush Valley floral assemblage (in orange, $\mathrm{n}=$ 11 ) and $D_{\mathrm{v}}$ density curve of the PNM litter assemblage (in black, $\mathrm{n}=18$ ) Left y axis (Density) refers to the density curves; right y axis (Frequency) refers to the histogram. B. Bootstrap histogram of PNM leaf litter average $D_{\mathrm{v}},(\mathrm{n}=11 ; 10,000$ repetitions $)$; orange line represents Mush Valley $D_{\mathrm{v}}$ average. 


\begin{tabular}{|c|c|c|c|c|c|c|c|}
\hline \multirow[t]{2}{*}{ Site } & \multicolumn{2}{|c|}{ Average $D_{\mathrm{v}}$ sun-demanding } & \multirow[t]{2}{*}{ p-value } & \multicolumn{2}{|c|}{$\begin{array}{c}\text { Average } D_{\mathrm{v}} \text { shade- } \\
\text { tolerant }\end{array}$} & \multirow[t]{2}{*}{ p-value } & \multirow[t]{2}{*}{ n } \\
\hline & canopy & understorey & & canopy & understorey & & \\
\hline PNM & $\begin{array}{c}13.81 \pm 3.85 \\
(6)\end{array}$ & $\begin{array}{c}8.67 \\
(1)\end{array}$ & NA & $\begin{array}{c}10.71 \pm 1.33 \\
\text { (3) }\end{array}$ & $\begin{array}{c}7.59 \\
(1)\end{array}$ & NA & 11 \\
\hline FTS & $\begin{array}{c}12.59 \pm 4.14 \\
(10)\end{array}$ & $\begin{array}{c}8.19 \\
(1)\end{array}$ & NA & $\begin{array}{c}10.33 \pm 2.52 \\
(15)\end{array}$ & $\begin{array}{c}5.81 \pm 2.07 \\
\quad(7)\end{array}$ & 0.0011 & 33 \\
\hline SERC & $\begin{array}{c}10.03 \pm 2.71 \\
\text { (7) }\end{array}$ & $\begin{array}{c}5.09 \pm 0.72 \\
\text { (7) }\end{array}$ & 0.0006 & $\begin{array}{c}11.47 \pm 2.34 \\
\text { (7) }\end{array}$ & $\begin{array}{c}6.77 \pm 1.83 \\
(10=\end{array}$ & 0.0019 & 31 \\
\hline TOTAL & $\begin{array}{c}12.11 \pm 3.81 \\
(23)\end{array}$ & $\begin{array}{c}5.83 \pm 1.6 \\
(9)\end{array}$ & $9.62 \times 10^{-6}$ & $\begin{array}{c}10.7 \pm 2.3 \\
(25)\end{array}$ & $\begin{array}{c}6.44 \pm 1.9 \\
(18)\end{array}$ & $1.5 \times 10^{-7}$ & 75 \\
\hline
\end{tabular}

Table 1. Average $D_{\mathrm{v}}$ values of sun-demanding and shade tolerant species in both canopy and understorey strata in PNM, FTS, SERC forests, and all forests together (TOTAL). Canopy versus understorey values were compared using Wilcoxon rank-sum tests, and $p$-values were indicated as "NA" when the sample size (in parenthesis) was too small to allow any statistical test. Ecological strategy was determined for all temperate but few tropical species because little knowledge on plant ecology has been acquired on tropical species, also due to their higher diversity. 


\begin{tabular}{cccc} 
Specimen & Morphotype & $\begin{array}{c}\text { Area } \\
\text { measured } \\
\left(\mathbf{m m}^{\mathbf{2}}\right)\end{array}$ & $\begin{array}{c}\text { Vein density } \\
\left(\mathbf{m m} / \mathbf{m m}^{2} \mathbf{)}\right.\end{array}$ \\
\hline MU33-19\#2 & Dinosaur footprint & 1.18 & 13.96 \\
MU27-38\#1 & Flaky Imposter & 6.41 & 14.77 \\
MU32-26\#1 & Herbie & 0.75 & 18.8 \\
MU23-26\#3 & Interrupt (Fabaceae) & 15.56 & 9.56 \\
MU32-20\#2 & Interrupt (Fabaceae) & 10.14 & 10.14 \\
MU18-17 & InterruptC (Fabaceae) & 1.42 & 20.09 \\
MU7-35B\#1 & Legume 1 (Fabaceae) & 16.3 & 13.59 \\
MU16-27 & Legume 4 (Fabaceae) & 6.29 & 15.69 \\
MUSH & Legume 4 (Fabaceae) & 4.15 & 10.73 \\
MU32-3B\#2 & Mushroom Trichomes & 5.69 & 9.88 \\
MU30-2 & Pinnate Truncate (Fabaceae) & 1.24 & 19.22 \\
MU17- & Short Drip Tip (Fabaceae) & 2.11 & 18.69 \\
28A\#1 & & & \\
MU18-13 & Short Drip Tip (Fabaceae) & 2.13 & 15.92 \\
MU18-14A & Short Drip Tip (Fabaceae) & 2.34 & 15.89 \\
\#2 & Short Drip Tip (Fabaceae) & 3.98 & 13.18 \\
MU27-9 & Shorl-toothed Euphorbeaceae & 3.54 & 23.53 \\
MU31-16\#1 & Small & \\
MU31-30 & Small-toothed Euphorbeaceae & 1.71 & 26.01
\end{tabular}

Table 2. Table showing specimens names, corresponding morphotypes, area measured and vein densities. 


\section{SUPPLEMENTARY MATERIAL I - Figures and Tables}
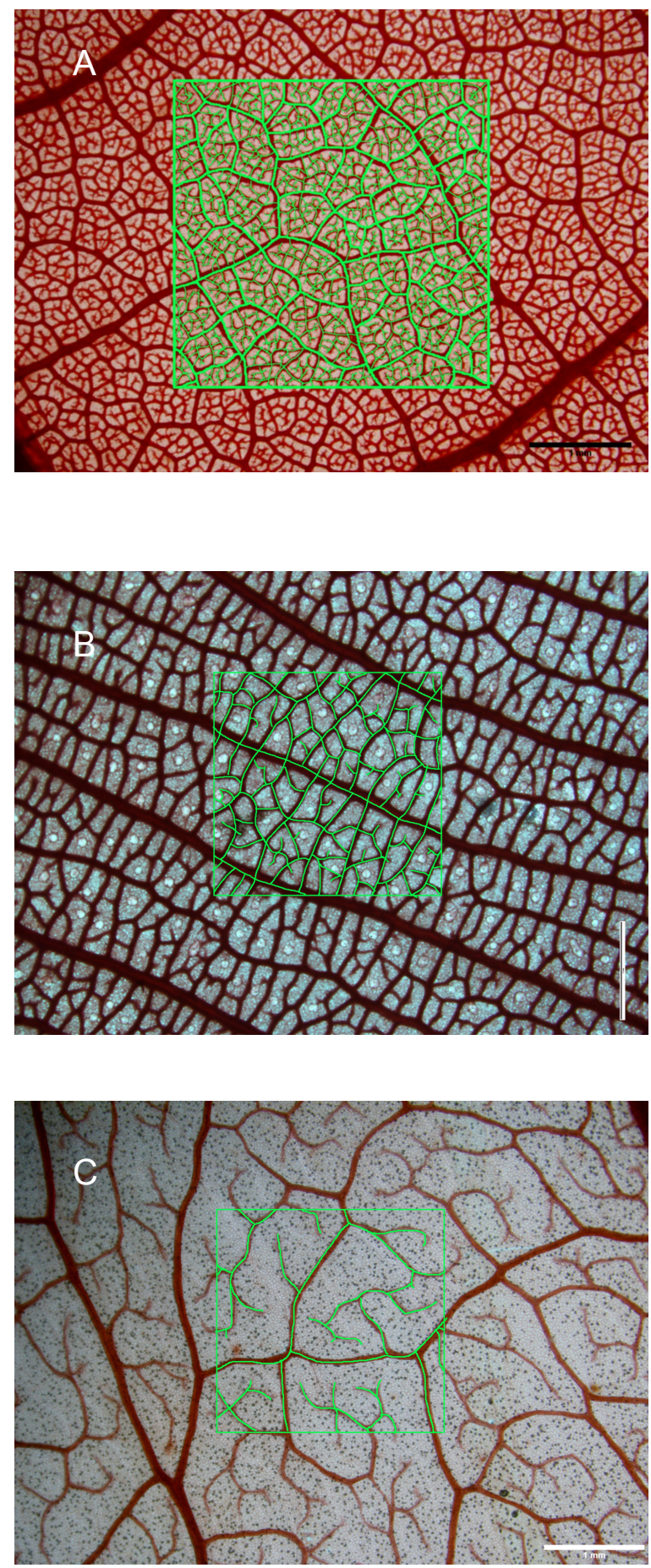

Figure1: Examples of vein density measurements of 3 different leaves. The area measured corresponds to the green square; area measured $=4 \mathrm{~mm}^{2}$. A. Coccoloba parimensis (Polygonaceae), canopy leaf; B. Tovomita longifolia (Clusiaceae), understorey leaf; C. Marila laxiflora (Clusiaceae), canopy leaf. 


\begin{tabular}{lcccc}
\multicolumn{1}{c}{ Species } & $\begin{array}{c}\text { Area } \\
(\mathbf{m m})\end{array}$ & $\mathbf{D v 1}$ & $\mathbf{D v 2}$ & \multicolumn{1}{c}{ Dv2-Dv1 } \\
\hline Luehea seemanii & 1 & 24.98401598 & 29.06893107 & 4.08491509 \\
Luehea seemanii & 2 & 25.20586773 & 29.12829438 & 3.92242665 \\
Luehea seemanii & 3 & 25.09000332 & 28.94287612 & 3.8528728 \\
Luehea seemanii & 4 & 25.27222777 & 27.6471029 & 2.37487513 \\
Luehea seemanii & 5 & 24.56080542 & 27.93361244 & 3.37280702 \\
Luehea seemanii & 6 & 25.45454545 & 28.3997669 & 2.94522145 \\
Luehea seemanii & 7 & $\mathrm{NA}$ & 28.29217168 & $\mathrm{NA}$ \\
Luehea seemanii & 8 & 25.36318284 & 28.33574457 & 2.97256173 \\
Luehea seemanii & 9 & $\mathrm{NA}$ & 28.81218781 & $\mathrm{NA}$ \\
Luehea seemanii & 10 & $\mathrm{NA}$ & 28.3874 & $\mathrm{NA}$ \\
Average & & 25.13294979 & 28.49480879 & 3.36081141 \\
& & & & \\
Ocotea ira & 1 & 3.548707753 & 3.226640159 & 0.322067594 \\
Ocotea ira & 2 & 3.306387226 & 3.410678643 & 0.104291417 \\
Ocotea ira & 3 & 3.176353371 & 3.189637994 & 0.013284623 \\
Ocotea ira & 4 & 3.315027459 & 3.354717923 & 0.039690464 \\
Ocotea ira & 5 & 3.329802119 & 3.38776734 & 0.057965221 \\
Ocotea ira & 6 & 3.395934011 & 3.45325779 & 0.057323779 \\
& 7 & 3.40076934 & 3.397919932 & 0.002849408 \\
Ocotea ira & 8 & 3.407633778 & 3.470250717 & 0.062616939 \\
Ocotea ira & 9 & 3.375333333 & 3.427222222 & 0.051888889 \\
Ocotea ira & 10 & 3.327606872 & 3.376648022 & 0.04904115 \\
Ocotea ira & & 3.358355526 & 3.369474074 & 0.011118548
\end{tabular}

Table 1: Table of vein density measurements of a high $D$ v canopy leaf of Luehea seemanii and an understorey leaf of Ocotea ira. The second column indicates the area measured. Dv1 and Dv2 are the vein density measurement obtained by two different people, using the same images and the same spots on each photo. $D$ v1 was measured by an undergraduate with no prior experience performing vein density analyses, and $D$ v2 was measured by the PI. The difference between $D$ v2 and $D \mathrm{v} 1$ are reported on the last column. Data show that varying the area measured does not affect the accuracy of the vein density measurements. Although there is no significant difference between $D \vee 1$ and Dv2 for Ocotea ira, Dv2 is consistently $3-4 \mathrm{~mm} / \mathrm{mm}^{2}$ higher than Dv1 for Luehea seemanii. This is probably due to the higher chance of misidentifying veins at high densities, caused by different experience working with leaves. However, Dv measurements obtained by an individual researcher are consistent with each other, suggesting that the technique is well reproducible. 
A

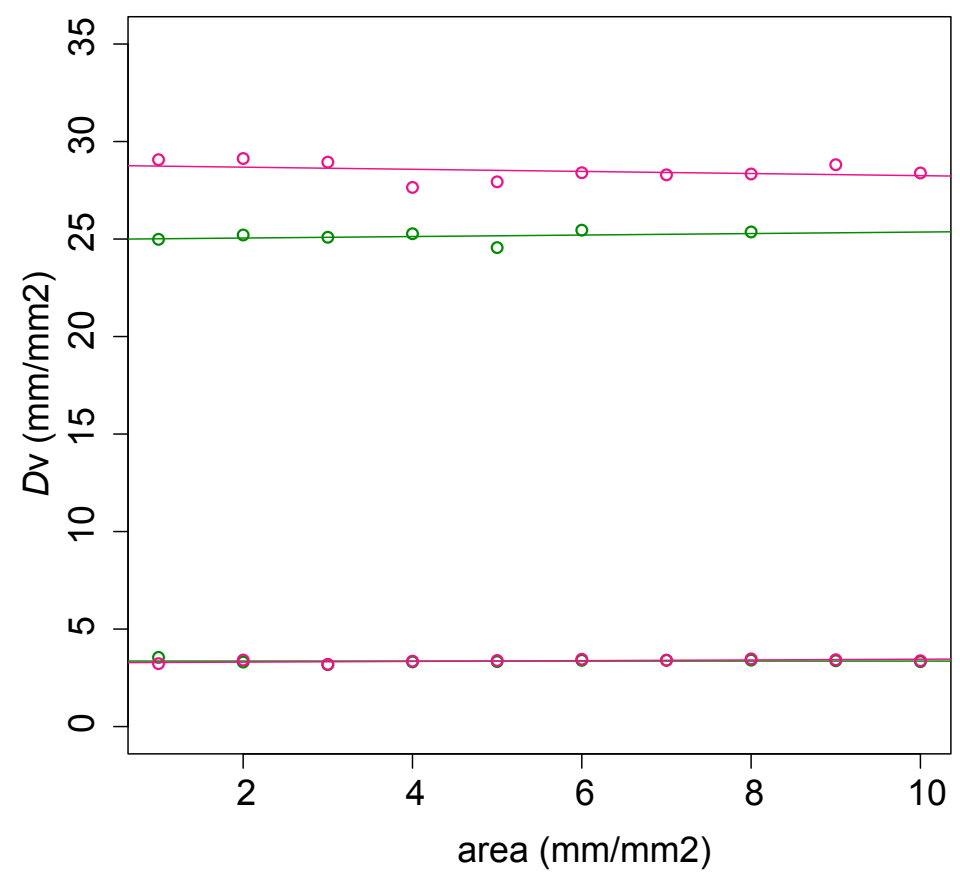

B

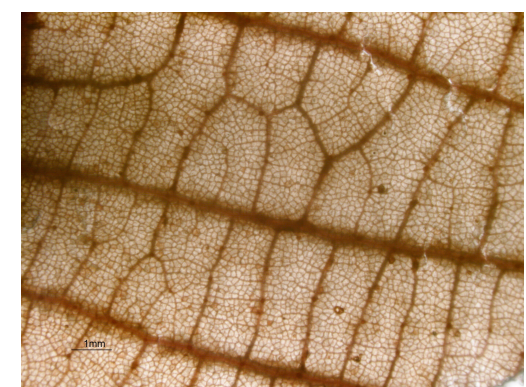

C

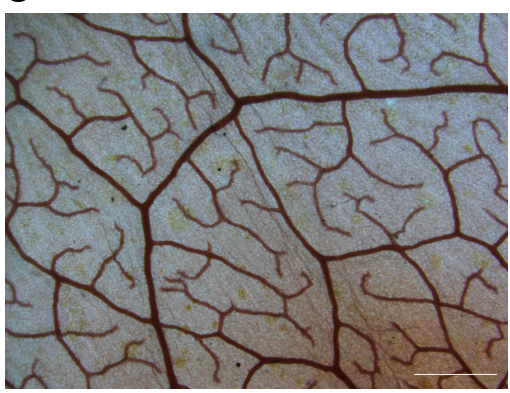

Figure 2: A. plot of Dv at different areas measured of a leaf of B. Luehea seemanii (Malvaceae) (upper points) and C. Ocotea ira (Lauraceae) (lowest points) by two different people (in pink and green). The $x$-axis corresponds to the area of the photo measured; the $y$-axis corresponds to vein density. 


\section{SUPPLEMENTARY MATERIAL II - R codes}

Codes to open and charge the csv file on $\mathbf{R}$

- Standing forests

data<-read.csv (file="Data

species. $\mathrm{csv}$, header=T, $\mathrm{fill}=\mathrm{T}$, na.strings="NA")

$\operatorname{attach}($ data)

- Litter

litter<-read.csv (file="litter.csv", header $=\mathrm{T})$

attach (litter)

- Cretaceous-Paleocene $D_{\mathrm{v}}$

paleo<-read.csv(file="paleo.csv", header=T,fill=T, na.strings="NA")

attach (paleo)

- Vein density of Mush Valley

mush<-read.csv (file="mush. csv", header=T)

attach (mush)

Codes to create vectors

- Vein density of the canopy species of FTS

CFTS $<-d v$ [Site=="FTS " \&Strata=="CANOPY" ]

- Vein density of the canopy species of SERC

CSERC $<-d v[$ Site=="SERC " \&Strata=="CANOPY" ]

- Vein density of the canopy species of PNM

CPNM $<-d v[$ Site=="PNM" \&Strata==" CANOPY" ]

- Vein density of the understorey species of FTS

UFTS $<-d v[$ Site=="FTS " \&Strata=="UNDERSTOREY" ]

- Vein density of the understorey species of SERC

USERC $<-d v$ [Site=="SERC" \&Strata== "UNDERSTOREY" ]

- Vein density of the understorey species of PNM

UPNM $<-d v[$ Site=="PNM" \&Strata==" UNDERSTOREY" ]

- Vein density of canopy and understorey of FTS

FTS<-C ( CFTS , UFTS ) 
- Vein density of canopy and understorey of SERC

SERC = SERC canopy+understorey

- Vein density of canopy and understorey of PNM

PNM $<-C$ ( CPNM, UPNM )

- Vector of vein density of all litter morphotypes

DVlitter<-DV

- Vector of all vein density of all fossil morphotypes

dvp $<-D V P$

- Vectors of fossil vein density for each age:

Hautaverian<-dvp [ $1: 2]$

Barremian<-dvp [ $3: 5$ ]

Aptian<-dvp [6:11]

Albian<-dvp [ 12:39]

Cenomanian<-dvp [ $40: 51$ ]

Campanian<-dvp [52:62]

Maastrichtian<-dvp [63:74]

Paleocene<-dvp [ $75: 105]$

- Vector of vein density of all Mush Valley morphotypes

$d v m=d v m$

FIGURE 2: comparison of canopy and understorey at FTS, SERC, and PNM, and PNM litter.

\section{Statistics}

- Mean Dv and standard deviation per site

mean (FTS)

$\operatorname{sd}($ FTS )

mean ( SERC)

$\operatorname{sd}(\mathrm{SERC})$

mean ( PNM)

$\operatorname{sd}(\mathrm{PNM})$ 
- Mean canopy Dv and standard deviation per site

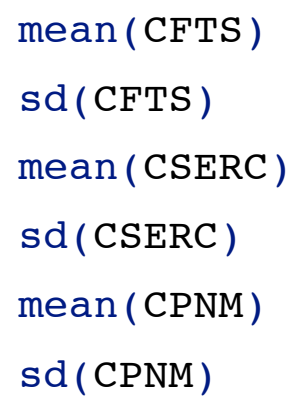

- Mean understorey Dv and standard deviation per site

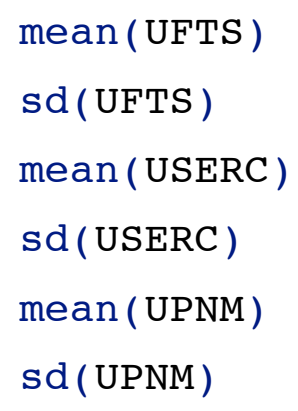

- Wilcoxon rank-sum test between sites : CANOPY

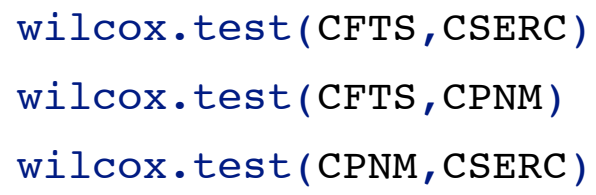

- Wilcoxon rank-sum test between sites : understorey

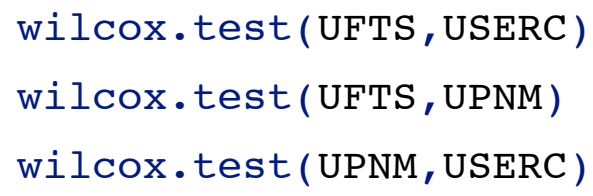

- Wilcoxon rank-sum test between sites : canopy and understorey

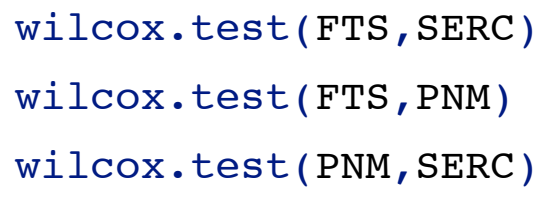

- Wilcoxon rank-sum test between litter and PNM (whole sample, canopy, understorey)

wilcox.test (DVlitter, PNM)

wilcox.test (DVlitter, CPNM)

wilcox.test (DVlitter, UPNM) 


\section{Graphics}

- Code to make 3 histograms on the same graphic (3 lines, 1 column) $\operatorname{par}(\operatorname{mfrow}=\mathrm{c}(3,1))$

○ Graphic A (FTS):

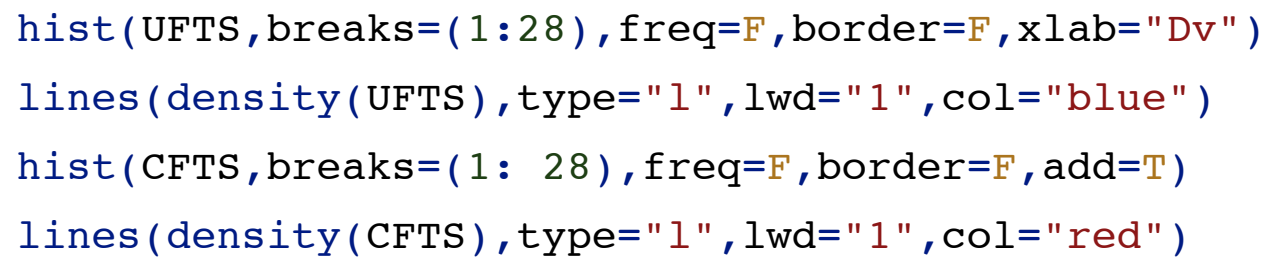

FIGURE 3: Comparisons of the PNM litter and Cretaceous-Paleocene fossil floras

\section{Statistics}

- Wilcoxon rank-sum test between the litter vein density (DV) and the vein density of each one of the 8 paleofloras

wilcox.test (Hautaverian, DVlitter)

wilcox.test (Barremian, DVlitter)

wilcox.test (Aptian, DVlitter) 
wilcox.test (Albian, DVlitter)

wilcox.test (Cenomanian, DVlitter)

wilcox.test (Campanian, DVlitter)

wilcox.test (Maastrichtian, DVlitter)

wilcox.test (Paleocene, DVlitter)

\section{Graphics}

- Code to make 8 graphics on the same image ( 2 lines, 4 column) $\operatorname{par}(\operatorname{mfrow}=\mathrm{c}(2,4))$

\section{- Histogram of the Hautaverian + PNM modern litter}

hist $(\operatorname{dvp}[3]$, border $=F$, breaks $=(1: 28)$, freq $=F, x l a b=" D v "$, main=paste $("$ Hautaverian" ), ylim $=\mathrm{c}(0,0.6))$

lines (density (dvp [3]), type="p", pch="o" , col="white" )

hist ( Hautaverian, border="darkgreen ", breaks=( $1: 28)$, freq=F, add $=\mathrm{T}, \mathrm{xl} \mathrm{ab}=$ " Dv" )

lines (density (Hautaverian), type="p", pch="o" ,col="darkgreen" )

hist (DVlitter, breaks=(1:28), border $=F$, freq $=F$, add=TRUE)

lines (density (DVlitter), type="p", pch="०")

text $(10,0.5$, labels $=" n=2 ", c o l="$ darkgreen" $)$

- Histogram of the Barremian + PNM modern litter

hist $(\operatorname{dvp}[3]$, border $=F$, breaks $=(1: 28)$, freq $=F, x l a b=" D v "$, main=paste $("$ Barremian" ), ylim $=c(0,0.6))$

lines (density (dvp [3]), type="p", pch="o" , col="white" )

hist (Barremian, border="darkgreen" , breaks $=(1: 28)$, freq $=\mathrm{F}$, add $=\mathrm{T}$ )

lines (density (Barremian), type="p", pch=" " , col="darkgreen" )

hist ( DVlitter , breaks $=(1: 28)$, border $=F$, freq $=F$, add=TRUE )

lines (density (DVlitter), type = "p", pch="o")

text $(10,0.5$, labels $=" n=3 ", \operatorname{col}="$ darkgreen" $)$

- Histogram of the Aptian + PNM modern litter

hist $(\operatorname{dvp}[3]$, border $=F$, breaks $=(1: 28)$, freq $=F, x l a b=" D v "$, main=paste $("$ Aptian"), ylim=c $(0,0.6))$

lines (density (dvp [3]), type="p", pch="o" , col="white" )

hist (Aptian, border="darkgreen" , breaks $=(1: 28)$, freq $=F$, add=T $)$ 
lines (density (Aptian), type="p", pch="o" , col="darkgreen" )

hist ( DVlitter, breaks $=(1: 28)$, border $=F$, freq $=F$, add=TRUE )

lines (density (DVlitter), type="p" , pch="o")

text $(10,0.5$, labels $=" n=6 ", c o l="$ darkgreen $")$

- Histogram of the Albian + PNM modern litter

hist ( $\operatorname{dvp}[3]$, border $=F$, breaks $=(1: 28)$, freq $=F, x l a b=" D v "$, main=paste $("$ Albian"),ylim=c $(0,0.6))$

lines (density (dvp [3]), type="p",pch="o" , col="white" )

hist (Albian, border="darkgreen" , breaks=( $1: 28)$, freq $=F$, add=T, $\mathrm{xlab}=$ "Dv")

lines (density (Albian), type="p", pch="o" , col="darkgreen" )

hist (DVlitter, breaks $=(1: 28)$, border $=F$, freq $=F$, add $=$ TRUE $)$

lines (density (DVlitter), type="p", pch="o")

text $(10,0.5$, labels $=" n=28 ", c o l="$ darkgreen $")$

- Histogram of the Cenomanian + PNM modern litter

hist $(\operatorname{dvp}[3]$, border $=F$, breaks $=(1: 28)$, freq $=F, x l a b=" D v "$, main=paste $($ "C enomanian"), $y \lim =c(0,0.6))$

lines (density (dvp [3]), type="p", pch="o" , col="white" )

hist (Cenomanian, border="darkgreen" , breaks=( $1: 28)$, freq=F, add $=\mathrm{T}, \mathrm{xl} \mathrm{ab}=$ " Dv" )

lines (density (Cenomanian), type="p" , pch="o" ,col="darkgreen" )

hist $($ DVlitter, breaks $=(1: 28)$, border $=F$, freq $=F$, add=TRUE $)$

lines (density (DVlitter), type="p" , pch="o")

text $(10,0.5$, label $s=" n=12 ", \operatorname{col}=$ "darkgreen" $)$

- Histogram of the Campanian + PNM modern litter

hist $(\operatorname{dvp}[3]$, border $=F$, breaks $=(1: 28)$, freq $=F, x l a b=" D v "$, main=paste $("$ Campanian" ), ylim=c $(0,0.6))$

lines (density (dvp [3]), type="p", pch="o" , col="white" )

hist (Campanian, border $="$ darkgreen" , breaks $=(1: 28)$, freq $=\mathrm{F}$, add $=\mathrm{T}$, $\mathrm{xlab}=$ "Dv" )

lines (density (Campanian), type="p",pch=" " , col="darkgreen" )

hist $($ DVlitter, breaks $=(1: 28)$, border $=F$, freq $=F$, add=TRUE $)$ 


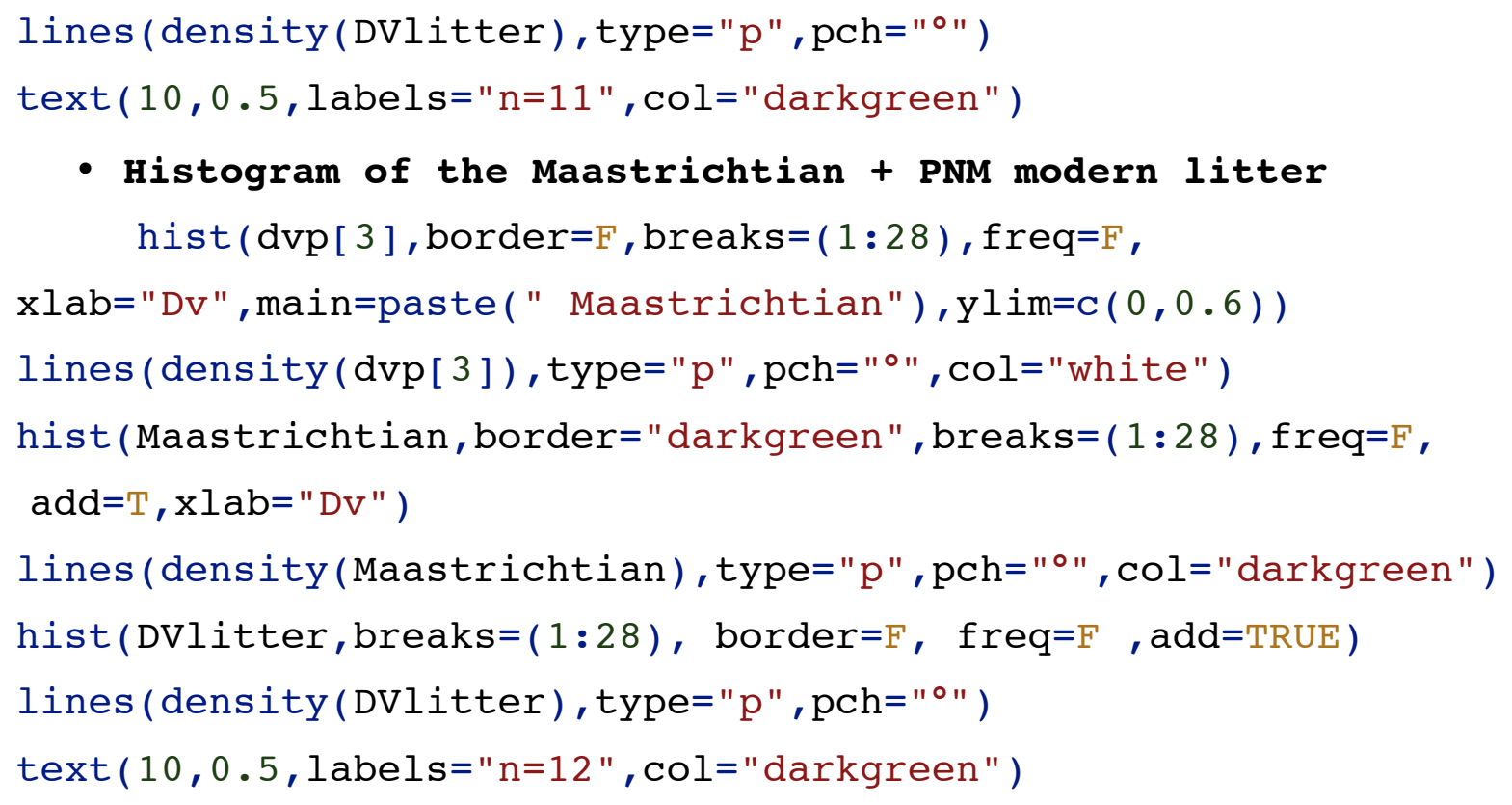

- Histogram of the Maastrichtian + PNM modern litter

hist $(\operatorname{dvp}[3]$, border $=F$, breaks $=(1: 28)$, freq $=F$,

- Histogram of the Paleocene + PNM modern litter

hist $(\operatorname{dvp}[3]$, border $=F$, breaks=(1:28), freq $=F, x l a b=" D v "$, main=paste $($ " Paleocene"), ylim=c $(0,0.6))$

lines (density $(\operatorname{dvp}[3])$, type="p",pch="o" , col="white")

hist (Paleocene, border="darkgreen" , breaks=(1:28), freq $=\mathrm{F}, \quad \operatorname{add}=\mathrm{T}$, $\mathrm{xlab}=" \mathrm{Dv} "$ )

lines (density (Paleocene), type="p",pch=" " , col="darkgreen")

hist (DVlitter, breaks= ( 1:28), border $=F$, freq $=F$, add=TRUE )

lines (density (DVlitter), type="p", pch="०")

text $(10,0.5$, labels $=" n=31 ", \operatorname{col}="$ darkgreen $")$

FIGURE 4: Comparisons of the PNM litter and the Mush Valley fossil assemblage

\section{Statistics}

proba $=(X) / \operatorname{sum}(X)$

proba $=$ probability for each vein density value to be extracted randomly from the litter assemblage ( $\mathrm{X}=$ number of leaves of the same morphotype)

- Code for a Bootstrap with $\mathbf{1 0 , 0 0 0}$ repetitions of a subsample of 10 morphotypes, with replacement

m=numeric ( )

$\mathrm{d}=$ numeric ( ) 
for $(\mathrm{n}$ in $1: 10000)\{$

ls =sample (DVlitter , 10 , replace $=\mathrm{T}$, prob=proba $)$

$\mathrm{m}[\mathrm{n}]=\operatorname{mean}(\mathrm{ls})$

$d[n]=s d(l s)\}$

- Percentage of mean vein density of the bootstrap equal or lower than Mush valley mean vein density:

minor $<-$ length (which $(\mathrm{m}<=$ mean $(\mathrm{dvm}))$ )

minor $/ 100$

- Percentage of mean vein density of the bootstrap equal or higher than Mush valley mean vein density:

major $<-$ length (which $(\mathrm{m}>=$ mean $(\mathrm{dvm}))$ )

major/100

\section{Graphics}

- Code to make 2 graphics on the same image (1 line, 2 columns) $\operatorname{par}(\operatorname{mfrow}=\mathrm{c}(1,2))$

- Histogram and density curve of Mush vein density + PNM modern litter density curve

$\operatorname{par}(\operatorname{mar}=\mathrm{C}(5,5,3,5))$

hist $($ dvm, breaks $=(1: 28)$, border $=T, \operatorname{col}=$ "orange", freq $=F$, axes $=F$, xaxt $=n$

")

$\operatorname{axis}(2, \operatorname{col}=" \mathrm{black} ")$

lines (density $(\mathrm{dvm}), \mathrm{col}=$ "darkorange", type="p",pch="o" )

hist $($ DVlitter , border $=F$, breaks $=(1: 28)$, freq $=F$,

$\mathrm{xlab}=" \mathrm{Dv} ", \mathrm{ylim}=\mathrm{c}(0,0.6), \mathrm{add}=\mathrm{T})$

lines (density (DVlitter), type="p",pch="o" , col="black")

$\operatorname{par}($ new $=\mathrm{T})$

hist $($ dvm, breaks $=(1: 28)$, border $=F$, freq $=T$, axes $=F, y l a b=" ~ ")$

$\operatorname{axis}(4, \mathrm{col}=" \mathrm{black} ")$

$\operatorname{axis}(1, \mathrm{col}=" \mathrm{black} ")$

mtext ("Frequency", side=4, line=3)

- Histogram of the bootstrap (means of subsamples)

$\operatorname{par}(\operatorname{mar}=c(5,5,3,5))$ 
hist (m)

$a=$ mean $(d v m)$

abline ( $\mathrm{v}=\mathrm{a}, \mathrm{col}=$ "darkorange" ) 
SUPPLEMENTARY MATERIAL III - Row data

\section{1) Species list.xlsx}

\begin{tabular}{|c|c|c|c|c|c|}
\hline $\begin{array}{c}\text { Species } \\
\text { mnemonic } \\
\text { acronym }\end{array}$ & Genus & Species & Family & Ecology & Lifeform \\
\hline ACEPS & Acer & pseudoplatanus & Sapindaceae & sun-demanding & tree \\
\hline ALBG & Albizia & guachapele & Fabaceae & sun-demanding & understorey \\
\hline AMPP & Amphilophium & paniculatum & Bignoniaceae & & liana \\
\hline ANAE & Anacardium & excelsum & Anacardiaceae & & tree \\
\hline ANNS & Annona & sparaguei & Annonaceae & & midstorey \\
\hline ANTT & Antirrhoea & trichanta & Rubiaceae & sun-demanding & tree \\
\hline APEM & Apeiba & membranaceae & Tiliaceae & sun-demanding & tree \\
\hline ARIM & Aristolochia & maxima & Aristolochicaceae & & liana \\
\hline ARRV & Arrabidea & verrucosa & Bignoniaceae & & liana \\
\hline ASITR & Asimina & triloba & Annonaceae & shade-tolerant & midstorey \\
\hline ASTG & Astronium & graveolens & Anacardiaceae & & tree \\
\hline BERTH & Berberis & thunbergii & Berberidaceae & sun-demanding & shrub \\
\hline BONM & Bonamia & maripoide & Convolvulaceae & & vine \\
\hline BROA & Brosimum & alicastrum & Moraceae & sun-demanding & tree \\
\hline BROU & Brosimum & utile & Moraceae & shade-tolerant & tree \\
\hline CAL2 & Calophyllum & logifolium & Clusiaceae & shade-tolerant & tree \\
\hline CARG & Carapa & guianensis & Meliaceae & shade-tolerant & tree \\
\hline CARGL & Carya & glabra & Juglandaceae & shade-tolerant & understorey \\
\hline CARP1 & Carpinus & $\mathrm{sp}$ & Betulaceae & shade-tolerant & midstorey \\
\hline CARTO & Carya & tomentosa & Juglandaceae & shade-tolerant & tree \\
\hline CARY1 & Carya & $\mathrm{sp}$ & Juglandaceae & shade-tolerant & tree \\
\hline CAS4 & Castilla & elastica & Moraceae & sun-demanding & midstorey \\
\hline CECI & Cecropia & insignis & Cecropiaceae & sun-demanding & tree \\
\hline CECL & Cecropia & longipes & Cecropiaceae & sun-demanding & midstorey \\
\hline CES1 & Cespedezia & macrophylla & Ochnaceae & & tree \\
\hline CHRC & Chysophyllu & cainito & Sapotaceae & & tree \\
\hline CLUV & Clusia & valerioi & Clusiaceae & & hemiepiphyte \\
\hline COCP & Coccoloba & parimensis & Polygonaceae & & liana \\
\hline COMF & Combretum & fruticosum & Combretaceae & & liana \\
\hline CORB & Cordia & bicolor & Boraginaceae & sun-demanding & midstorey \\
\hline CORFL & Cornus & florida & Cornaceae & shade-tolerant & midstorey \\
\hline CYDA & Cydista & aequinoctalis & Bignoniaceae & sun-demanding & liana \\
\hline
\end{tabular}




\begin{tabular}{|c|c|c|c|c|c|}
\hline DAVN & Davilla & nitida & Dilleniaceae & & liana \\
\hline DENA & Dendropanax & arboreus & Araliaceae & & tree \\
\hline DIOW & Dioclea & wilsonii & Fabaceae & & liana \\
\hline DOL1 & Doliocarpus & major & Dilleniaceae & & liana \\
\hline DOL2 & Doliocarpus & multiflorus & Dilleniaceae & & liana \\
\hline DUSM & Dussia & munda & Fabaceae & & tree \\
\hline ELAUM & Elaeagnus & umbellata & Elaeagnaceae & sun-demanding & shrub \\
\hline FAGGR & Fagus & grandifolia & Fagaceae & shade-tolerant & tree \\
\hline FIIN & Ficus & insipida & Moraceae & sun-demanding & tree \\
\hline FORM & Forsteronia & myriantha & Apocynaceae & & liana \\
\hline FORS & Forsteronia & spicata & Apocynaceae & & liana \\
\hline FORV & Forsteronia & viridiscens & Apocynaceae & & liana \\
\hline FRAAM & Fraxinus & americana & Oleaceae & sun-demanding & tree \\
\hline FRAPE & Fraxinus & pennsylvanica & Oleaceae & shade-tolerant & tree \\
\hline FRAX1 & Fraxinus & $\mathrm{sp}$ & Oleaceae & & tree \\
\hline GOUL & Gouania & lupuloides & Rhamnaceae & & liana \\
\hline GUAD & Guatteria & dumetorum & Annonaceae & & tree \\
\hline GUAK & Guarea & kunthiana & Meliaceae & & tree \\
\hline GUAU & Guazuma & ulmifolia & Sterculiaceae & & midstorey \\
\hline HAVF & Havetiopsis & flexilis & Clusiaceae & & hemiepiphyte \\
\hline HEIS & Heisteria & scadens & Olacaceae & & liana \\
\hline ILEOP & Ilex & opaca & Aquifoliaceae & shade-tolerant & midstorey \\
\hline INGO & Inga & goldmanii & Cyperaceae & shade-tolerant & liana \\
\hline LACP & Lacmella & panamensis & Chrysobalanaceae & & tree \\
\hline LINBE & Lindera & benzoi & Lauraceae & shade-tolerant & shrub \\
\hline LIQST & Liquidambar & styraciflua & Altingiaceae & sun-demanding & tree \\
\hline LIRTU & Liriodendron & tulipifera & Magnoliaceae & sun-demanding & tree \\
\hline LONL & Lonchocarpus & longifolium & Fabaceae & shade-tolerant & tree \\
\hline LUE1 & Luehea & seemanii & Tiliaceae & & tree \\
\hline MACR & Machaerium & riparum & Fabaceae & & liana \\
\hline MANB & Manilkara & bidentata & Sapotaceae & shade-tolerant & tree \\
\hline MAR1 & Marcgravia & nephentoides & Marcgraviaceae & & hemiepiphyte \\
\hline MAR3 & Maranthes & panamensis & Chrysobalanaceae & & tree \\
\hline MARL & Marila & laxiflora & Clusiaceae & & midstorey \\
\hline MICB & Miconia & borealis & Melastomataceae & sun-demanding & shrub \\
\hline MIKL & Mikania & leiostachya & Asteraceae & & vine \\
\hline NEC2 & Nectandra & cuspidata & Lauraceae & shade-tolerant & midstorey \\
\hline NECU & Nectandra & umbrosa & Lauraceae & shade-tolerant & midstorey \\
\hline
\end{tabular}




\begin{tabular}{|c|c|c|c|c|c|}
\hline OCOI & Ocotea & ira & Lauraceae & shade-tolerant & midstorey \\
\hline ODOP & Odontadenia & ponticulosa & Apocynaceae & & liana \\
\hline OMPD & Omphalea & diandra & Euphorbiaceae & & liana \\
\hline PASV & Passiflora & vitifolia & Passifloraceae & & vine \\
\hline PAUF & Paulinia & fibrigera & Sapindaceae & & liana \\
\hline PAUTO & Paulownia & tomentosa & Paulowniaceae & sun-demanding & tree \\
\hline PERA & Pera & arborea & Euphorbiaceae & shade-tolerant & tree \\
\hline PERX & Perebea & xanthocyma & Moraceae & shade-tolerant & understorey \\
\hline PHI1 & Philodendron & $\mathrm{sp}$ & Araceae & & hemiepiphyte \\
\hline PITC & Pithecoctenium & crucigerum & Bignoniaceae & & liana \\
\hline POUA & Poulsenia & armata & Moraceae & shade-tolerant & tree \\
\hline POUB & Pouruma & bicolor & Cecropiaceae & sun-demanding & tree \\
\hline PPRE & Piper & reticulatum & Piperaceae & shade-tolerant & shrub \\
\hline PROP & Protium & panamense & Burseraceae & shade-tolerant & tree \\
\hline PYSU & Psychotria & surrensis & Rubiaceae & shade-tolerant & shrub \\
\hline QUEAL & Quercus & alba & Fagaceae & shade-tolerant & tree \\
\hline QUER1 & Quercus & $\mathrm{sp}$ & Fagaceae & shade-tolerant & tree \\
\hline QUERU & Quercus & rubra & Fagaceae & shade-tolerant & tree \\
\hline QUEVE & Quercus & velutina & Fagaceae & shade-tolerant & tree \\
\hline SAPG & Sapium & glandulosum & Sapindaceae & & tree \\
\hline SERM & Serjania & mexicana & Sapindaceae & & liana \\
\hline SMIRO & Smilex & rotundiolia & Smilacaceae & sun-demanding & woody vine \\
\hline SOCE & Socratea & exorrhiza & Arecacea & shade-tolerant & midstorey \\
\hline SPNA1 & NA & NA & na & & na \\
\hline STIR & Stizophyllum & riparium & Bignoniaceae & & liana \\
\hline SYMG & Symphonia & globulifera & Clusiaceae & shade-tolerant & tree \\
\hline TACV & Tachigali & cersicolor & Fabaceae & shade-tolerant & tree \\
\hline TOCP & Tocoyena & pittieri & Rubiaceae & shade-tolerant & understorey \\
\hline TONO & Tontelea & ovalifolia & Hippocrateaceae & & liana \\
\hline TOVL & Tovomita & longifolia & Clusiaceae & shade-tolerant & understorey \\
\hline TOXRA & Toxicodendron & radicans & Anacardiaceae & sun-demanding & shrub \\
\hline TRIO & Trichostigma & octandrum & Phytolacaceae & & liana \\
\hline TYNC & Tynnanthus & croatianus & Bignoniaceae & & liana \\
\hline UREC & Urera & caracasana & Urticaceae & sun-demanding & tree \\
\hline VAND & Vantanea & depleta & Humiriaceae & & tree \\
\hline VIBAC & Viburnum & acerifolium & Caprifoliaceae & shade-tolerant & shrub \\
\hline VIBPR & Viburnum & prunifolium & Caprifoliaceae & shade-tolerant & understorey \\
\hline VIRE & Virola & elongata & Myristicaceae & sun-demanding & tree \\
\hline
\end{tabular}




\begin{tabular}{|l|l|l|l|l|l|} 
VIR2 & Virola & surinamensis & Myristicaceae & shade-tolerant & tree \\
\hline VITLA & Vitis & labrusca & Vitaceae & sun-demanding & woody vine \\
\hline VITTT & Vitis & tilifolia & Vitaceae & & vine \\
\hline VOCF & Vochysia & ferruginea & Vichysiaceae & sun-demanding & tree \\
\hline
\end{tabular}




\section{2) Data species.csv}

\begin{tabular}{|c|c|c|c|c|c|c|}
\hline Site & $\begin{array}{l}\text { Species } \\
\text { mnemonic } \\
\text { acronym }\end{array}$ & Strata & Ecology & $\begin{array}{l}\text { Vein density } \\
\left(\mathbf{m m} / \mathbf{m m}^{2}\right)\end{array}$ & $\begin{array}{c}\text { Mean } \\
\text { squared error }\end{array}$ & $\mathbf{n}$ \\
\hline SERC & ACEPS & CANOPY & SUN-DEMANDING & 15.85516667 & 0.493520969 & 3 \\
\hline PNM & ALBG & CANOPY & SUN-DEMANDING & 16.23907867 & 0.181558841 & 9 \\
\hline PNM & AMPP & CANOPY & & 8.028200011 & 0.237258042 & 2 \\
\hline PNM & ANAE & CANOPY & & 11.92410985 & 0.237569928 & 15 \\
\hline PNM & ANNS & CANOPY & & 13.45341447 & 0.355841247 & 6 \\
\hline PNM & ANTT & CANOPY & SUN-DEMANDING & 18.89348751 & 0 & 1 \\
\hline FTS & APEM & CANOPY & SUN-DEMANDING & 12.04709677 & 0.329209232 & 3 \\
\hline PNM & ARIM & CANOPY & & 11.22770545 & 0.395427696 & 6 \\
\hline PNM & ARRV & CANOPY & & 11.75693338 & 0.298445504 & 3 \\
\hline SERC & ASITR & UNDERSTOREY & SHADE-TOLERANT & 4.820810824 & 0.10446418 & 3 \\
\hline PNM & ASTG & CANOPY & & 14.76282369 & 0.003561945 & 6 \\
\hline PNM & ASTG & UNDERSTOREY & & 10.47732004 & 0.637993855 & 3 \\
\hline SERC & BERTH & UNDERSTOREY & SUN-DEMANDING & 4.13116786 & 0.374233244 & 3 \\
\hline PNM & BONM & CANOPY & & 9.751242524 & 0.105613042 & 6 \\
\hline FTS & BROA & CANOPY & SUN-DEMANDING & 10.59397511 & 0.142960067 & 2 \\
\hline FTS & BROU & CANOPY & SHADE-TOLERANT & 10.67997269 & 0.876610956 & 8 \\
\hline FTS & BROU & UNDERSTOREY & & 6.066229065 & 0.01565856 & 11 \\
\hline FTS & CAL2 & CANOPY & SHADE-TOLERANT & 8.04630473 & 0.074529037 & 3 \\
\hline FTS & CAL2 & UNDERSTOREY & & 6.224753633 & 0.344402114 & 6 \\
\hline FTS & CARG & CANOPY & SHADE-TOLERANT & 11.12706778 & 0.135936852 & 6 \\
\hline SERC & CARGL & UNDERSTOREY & SHADE-TOLERANT & 7.416906455 & 0.844750506 & 2 \\
\hline SERC & CARP1 & UNDERSTOREY & SHADE-TOLERANT & 7.904658473 & 0.167262056 & 3 \\
\hline SERC & CARTO & CANOPY & SHADE-TOLERANT & 10.57122222 & 0.460714565 & 3 \\
\hline SERC & CARY1 & CANOPY & SHADE-TOLERANT & 11.18477778 & 1.97837483 & 3 \\
\hline FTS & CAS4 & CANOPY & SUN-DEMANDING & 12.27578982 & 0.009363797 & 1 \\
\hline PNM & CAS4 & UNDERSTOREY & SUN-DEMANDING & 8.671992102 & 0.002168288 & 6 \\
\hline FTS & CECI & CANOPY & SUN-DEMANDING & 19.34557664 & 0.731168381 & 3 \\
\hline PNM & CECL & CANOPY & SUN-DEMANDING & 12.85331304 & 0.256306392 & 1 \\
\hline FTS & CES1 & UNDERSTOREY & & 7.194697227 & 0.36239184 & 3 \\
\hline PNM & $\mathrm{CHRC}$ & UNDERSTOREY & & 7.0918191 & 0.018263216 & 6 \\
\hline FTS & CLUV & CANOPY & & 5.922601137 & 1.08432655 & 2 \\
\hline FTS & $\mathrm{COCP}$ & CANOPY & & 19.20944404 & 0.037605903 & 3 \\
\hline PNM & $\mathrm{COMF}$ & CANOPY & & 19.53771682 & 0.069992977 & 3 \\
\hline
\end{tabular}




\begin{tabular}{|c|c|c|c|c|c|c|}
\hline PNM & CORB & CANOPY & SUN-DEMANDING & 15.65099533 & 0.996607594 & 2 \\
\hline SERC & CORFL & CANOPY & SHADE-TOLERANT & 6.743888889 & 0.032968903 & 3 \\
\hline FST & CYDA & CANOPY & SUN-DEMANDING & 7.594184641 & 0.226591097 & 2 \\
\hline FST & DAVN & CANOPY & & 9.052806221 & 0.150496753 & 3 \\
\hline FTS & DENA & UNDERSTOREY & & 4.288706437 & 0.038681486 & 3 \\
\hline FST & DIOW & CANOPY & & 10.28229908 & 0.064131727 & 3 \\
\hline FST & DOL1 & CANOPY & & 7.766447049 & 1.13306341 & 3 \\
\hline PNM & DOL1 & UNDERSTOREY & & 4.849754319 & 0.956370952 & 9 \\
\hline FTS & DOL2 & UNDERSTOREY & & 4.711900962 & 0.109998414 & 3 \\
\hline FST & DUSM & CANOPY & & 11.07505811 & 0.181500404 & 9 \\
\hline SERC & ELAUM & UNDERSTOREY & SUN-DEMANDING & 5.177048031 & 0.060688234 & 3 \\
\hline SERC & FAGGR & UNDERSTOREY & SHADE-TOLERANT & 8.202155886 & 1.063181313 & 13 \\
\hline PNM & FIIN & CANOPY & SUN-DEMANDING & 10.82849505 & 0.101548907 & 5 \\
\hline FTS & FORM & CANOPY & & 10.11473029 & 1.884400597 & 3 \\
\hline PNM & FORS & CANOPY & & 15.37860672 & 0.401523783 & 3 \\
\hline FTS & FORV & CANOPY & & 8.533244742 & 0.142960067 & 3 \\
\hline SERC & FRAAM & UNDERSTOREY & SUN-DEMANDING & 5.613221162 & 0.270187453 & 6 \\
\hline SERC & FRAPE & CANOPY & SHADE-TOLERANT & 13.43036727 & 0.104119958 & 8 \\
\hline SERC & FRAX1 & UNDERSTOREY & & 7.082293748 & 0.105758918 & 3 \\
\hline PNM & GOUL & CANOPY & & 12.41565182 & 0.087658587 & 3 \\
\hline FTS & GUAD & CANOPY & & 10.50577752 & 0.336710603 & 6 \\
\hline FTS & GUAK & CANOPY & & 9.521106167 & 0.180440547 & 3 \\
\hline PNM & GUAU & CANOPY & & 15.25203174 & 1.424998594 & 3 \\
\hline FTS & HAVF & CANOPY & & 8.034049733 & 0.015231606 & 9 \\
\hline FTS & HEIS & CANOPY & & 9.860882964 & 0.059315639 & 3 \\
\hline FTS & HEIS & UNDERSTOREY & & 7.580771569 & 0.27755892 & 3 \\
\hline SERC & ILEOP & UNDERSTOREY & SHADE-TOLERANT & 6.599277474 & 0.221732812 & 5 \\
\hline FTS & INGO & CANOPY & SHADE-TOLERANT & 15.97155044 & 0.64382431 & 3 \\
\hline FTS & LACP & CANOPY & & 6.786839771 & 0.159407777 & 3 \\
\hline SERC & LINBE & UNDERSTOREY & SHADE-TOLERANT & 5.56479653 & 0 & 3 \\
\hline SERC & LIQST & CANOPY & SUN-DEMANDING & 9.930118056 & 0.245605722 & 1 \\
\hline SERC & LIQST & CANOPY & SUN-DEMANDING & 8.40125 & 0.565192678 & 4 \\
\hline SERC & LIQST & UNDERSTOREY & SUN-DEMANDING & 6.370232457 & 0.10036576 & 6 \\
\hline SERC & LIRTU & CANOPY & SUN-DEMANDING & 8.616001775 & 0.354355473 & 8 \\
\hline SERC & LIRTU & CANOPY & SUN-DEMANDING & 7.80226814 & 0.192803925 & 3 \\
\hline SERC & LIRTU & UNDERSTOREY & SUN-DEMANDING & 4.819676214 & 0 & 1 \\
\hline PNM & LONL & CANOPY & SHADE-TOLERANT & 11.53167323 & 0.178243623 & 3 \\
\hline PNM & LUE1 & CANOPY & & 27.17881768 & 0.232288269 & 3 \\
\hline
\end{tabular}




\begin{tabular}{|c|c|c|c|c|c|c|}
\hline PNM & LUE1 & UNDERSTOREY & & 12.8459288 & 0 & 3 \\
\hline FTS & MACR & CANOPY & & 13.57602998 & 0.104604076 & 3 \\
\hline FTS & MANB & CANOPY & SHADE-TOLERANT & 8.563040252 & 0.244409029 & 12 \\
\hline FTS & MAR1 & CANOPY & & 5.723590331 & 0.330251761 & 3 \\
\hline FTS & MAR3 & CANOPY & & 13.04418719 & 0.040157542 & 3 \\
\hline FTS & MARL & CANOPY & & 8.728232247 & 0.183249116 & 3 \\
\hline FTS & MARL & UNDERSTOREY & & 5.601314664 & 0.24741691 & 6 \\
\hline FTS & MICB & CANOPY & SUN-DEMANDING & 12.29072117 & 0.766695878 & 3 \\
\hline PNM & MIKL & CANOPY & & 7.20724056 & 0.072541578 & 6 \\
\hline PNM & NEC2 & CANOPY & SHADE-TOLERANT & 8.716798891 & 0.056735443 & 3 \\
\hline FTS & NECU & CANOPY & SHADE-TOLERANT & 9.152810733 & 0.113923398 & 3 \\
\hline FTS & OCOI & CANOPY & SHADE-TOLERANT & 8.775788833 & 0.016402727 & 3 \\
\hline FTS & OCOI & UNDERSTOREY & SHADE-TOLERANT & 3.151005863 & 0.326333152 & 3 \\
\hline FTS & ODOP & CANOPY & & 9.684395566 & 0.582734288 & 3 \\
\hline FTS & OMPD & CANOPY & & 9.553638588 & 0.025929049 & 3 \\
\hline PNM & PASV & CANOPY & & 13.22322228 & 0.56350439 & 2 \\
\hline FTS & PAUF & CANOPY & & 8.5518328 & 2.186200663 & 3 \\
\hline SERC & PAUTO & CANOPY & SUN-DEMANDING & 10.26930679 & 0.31657432 & 3 \\
\hline FTS & PERA & CANOPY & SHADE-TOLERANT & 10.32122171 & 1.214468011 & 3 \\
\hline FTS & PERX & UNDERSTOREY & SHADE-TOLERANT & 7.485640342 & 0.010951935 & 1 \\
\hline PNM & PHI1 & CANOPY & & 24.77509487 & 0.100874432 & 3 \\
\hline PNM & PITC & CANOPY & & 11.28205944 & 0.004410546 & 3 \\
\hline FTS & POUA & CANOPY & SHADE-TOLERANT & 12.42140147 & 0.303644592 & 3 \\
\hline FTS & POUA & UNDERSTOREY & SHADE-TOLERANT & 4.619937243 & 1.938793594 & 3 \\
\hline FTS & POUB & CANOPY & SUN-DEMANDING & 18.80018639 & 0.034074307 & 3 \\
\hline FTS & POUB & UNDERSTOREY & SUN-DEMANDING & 8.181989633 & 0.772234933 & 3 \\
\hline PNM & PPRE & CANOPY & SHADE-TOLERANT & 11.23899169 & 0.018212633 & 4 \\
\hline PNM & PPRE & UNDERSTOREY & SHADE-TOLERANT & 11.36714661 & 0.204449633 & 9 \\
\hline FTS & PROP & CANOPY & SHADE-TOLERANT & 13.25781456 & $1.52 \mathrm{E}-05$ & 3 \\
\hline FTS & PROP & UNDERSTOREY & SHADE-TOLERANT & 9.48496832 & 0.435765016 & 3 \\
\hline FTS & PYSU & UNDERSTOREY & SHADE-TOLERANT & 5.538959067 & 0.033044101 & 3 \\
\hline SERC & QUEAL & CANOPY & SHADE-TOLERANT & 13.28188889 & 0.172333571 & 3 \\
\hline SERC & QUEAL & UNDERSTOREY & SHADE-TOLERANT & 9.744346673 & 0.022672052 & 6 \\
\hline SERC & QUER1 & CANOPY & SHADE-TOLERANT & 12.836125 & 0.362244986 & 2 \\
\hline SERC & QUERU & UNDERSTOREY & SHADE-TOLERANT & 8.2995828 & 0.010715374 & 3 \\
\hline SERC & QUEVE & CANOPY & SHADE-TOLERANT & 12.27866667 & 0.425811681 & 3 \\
\hline FTS & SAPG & CANOPY & & 10.56035533 & 0.596778724 & 6 \\
\hline PNM & SERM & UNDERSTOREY & & 7.586520626 & 1.378258183 & 7 \\
\hline
\end{tabular}




\begin{tabular}{|c|c|c|c|c|c|c|}
\hline SERC & SMIRO & UNDERSTOREY & SUN-DEMANDING & 4.756640964 & 0.21038294 & 3 \\
\hline FTS & SOCE & CANOPY & SHADE-TOLERANT & 9.580721274 & 0.00775835 & 3 \\
\hline FTS & SPNA1 & CANOPY & & 10.53493949 & 0.082183275 & 3 \\
\hline SERC & SPNA2 & CANOPY & & 12.53676389 & 0.228771784 & 3 \\
\hline SERC & SPNA2 & UNDERSTOREY & & 4.955173944 & 0.151436142 & 3 \\
\hline PNM & STIR & CANOPY & & 10.85704441 & 0.041234725 & 3 \\
\hline FTS & SYMG & CANOPY & SHADE-TOLERANT & 9.464458426 & 0.67559637 & 3 \\
\hline FTS & TACV & CANOPY & SHADE-TOLERANT & 10.44015969 & 0.364234672 & 3 \\
\hline FTS & TACV & UNDERSTOREY & SHADE-TOLERANT & 4.902106313 & 0.037481477 & 6 \\
\hline FTS & TOCP & CANOPY & SHADE-TOLERANT & 12.05238431 & 0 & 1 \\
\hline FTS & TONO & CANOPY & & 6.442966801 & 0.173327755 & 3 \\
\hline FTS & TONO & UNDERSTOREY & & 5.206648411 & 0.152380935 & 3 \\
\hline FTS & TOVL & CANOPY & SHADE-TOLERANT & 5.137194825 & 0.011651414 & 3 \\
\hline SERC & TOXRA & UNDERSTOREY & SUN-DEMANDING & 4.74802019 & 0.075258044 & 2 \\
\hline PNM & TRIO & CANOPY & & 9.963486386 & 0.005384436 & 3 \\
\hline PNM & TYNC & CANOPY & & 8.882147379 & 0.231836374 & 3 \\
\hline PNM & UREC & CANOPY & SUN-DEMANDING & 8.401182499 & 0 & 1 \\
\hline FTS & VAND & CANOPY & & 10.90956267 & 3.605209054 & 3 \\
\hline SERC & VIBAC & UNDERSTOREY & SHADE-TOLERANT & 4.120487556 & 0.191974124 & 3 \\
\hline SERC & VIBPR & UNDERSTOREY & SHADE-TOLERANT & 5.056225864 & 0.114797839 & 9 \\
\hline FTS & VIRE & CANOPY & SUN-DEMANDING & 8.013553504 & 0.626993051 & 2 \\
\hline FTS & VIRE & UNDERSTOREY & SHADE-TOLERANT & 5.520908679 & 0.117606353 & 3 \\
\hline FTS & VIRS & CANOPY & SUN-DEMANDING & 7.347092406 & 0 & 1 \\
\hline SERC & VITLA & CANOPY & SUN-DEMANDING & 9.361333333 & 0 & 1 \\
\hline PNM & VITT & CANOPY & & 13.58494121 & & 1 \\
\hline FTS & VOCF & CANOPY & SUN-DEMANDING & 12.65134581 & 0.809531367 & 3 \\
\hline FTS & TOVL & UNDERSTOREY & SHADE-TOLERANT & 3.810767854 & 0.051554996 & 3 \\
\hline
\end{tabular}

Site: FTS= Parque National San Lorenzo (Panama), PNM = Parque Natural Metropolitano

(Panama), SERC= Smithsonian Environmental Research Center (MD)

Species mnemonic acronym $=4$ or 5 letter acronym of the genus and species

Strata: Canopy or understorey

Ecology: Ecological strategy of the species; sun-demanding or shade tolerant

dv : vein density $(\mathrm{mm} / \mathrm{mm} 2)$

n: number of leaves measured per species

Mean squared error: $\quad \mathrm{MSE}=\frac{1}{n} \sum_{i=1}^{n}\left(\hat{Y}_{i}-Y_{i}\right)^{2}$. 
3) litter.csv

\begin{tabular}{|c|c|c|}
\hline Morphotype & DV $\left(\mathbf{m m} / \mathbf{m m}^{2}\right)$ & $\mathbf{X}$ \\
\hline 1 & 1.10743684 & 1 \\
\hline 2 & 4.824953517 & 1 \\
\hline 3 & 6.231539322 & 2 \\
\hline 4 & 6.825159892 & 1 \\
\hline 5 & 7.669427711 & 1 \\
\hline 6 & 8.211364157 & 1 \\
\hline 7 & 8.902658303 & 3 \\
\hline 8 & 9.124082632 & 8 \\
\hline 9 & 9.39452562 & 2 \\
\hline 10 & 9.689252652 & 1 \\
\hline 11 & 10.57745802 & 2 \\
\hline 12 & 10.58878326 & 2 \\
\hline 13 & 11.2505666 & 1 \\
\hline 14 & 12.23157338 & 1 \\
\hline 15 & 13.10902425 & 84 \\
\hline 16 & 15.20372922 & 1 \\
\hline 17 & 21.58700661 & 2 \\
\hline 18 & 25.29665316 & 17 \\
\hline
\end{tabular}

Morphotype: ID number of the morphotypes

DV: vein density

$\mathbf{X}$ : number of leaves collected of each morphotype 


\section{4) mush.csv}

\begin{tabular}{|l|r|r|}
\hline \multicolumn{1}{|c|}{ morphotype } & Dvm $\left(\mathbf{m m} / \mathbf{m m}^{2}\right)$ & n \\
\hline Dinosaur footprint & 13.96317916 & 1 \\
\hline Flaky Imposter & 14.76635813 & 1 \\
\hline Herbie & 18.79840849 & 1 \\
\hline Interrupt & 9.850056981 & 2 \\
\hline InterruptC & 20.08796367 & 1 \\
\hline Legume 1 & 13.58529671 & 1 \\
\hline Legume 4 & 13.2109941 & 2 \\
\hline Mushroom Trichomes & 9.879107363 & 1 \\
\hline Pinnate truncate & 19.22375362 & 1 \\
\hline Short Drip Tip & 15.92060103 & 4 \\
\hline Small-tooth Euphorb & 24.76817674 & 1 \\
\hline
\end{tabular}

morphotype: name of the morphotype

dvm: average vein density of each morphotype

n: number of specimens measured per morphotype 


\section{4) paleo.csv}

\begin{tabular}{|c|c|c|c|c|}
\hline Morphotype & $\begin{array}{c}\text { DVP } \\
\left(\mathrm{mm} / \mathrm{mm}^{2}\right)\end{array}$ & AGE1 & AGE2 & Formation \\
\hline Asiatifolium elegans & 3.67 & 132.35 & $\begin{array}{l}\text { Hauterivian-Early } \\
\text { Barremian }\end{array}$ & $\begin{array}{l}\text { Chengzihe Formation, } \\
\text { near Jixi, China }\end{array}$ \\
\hline Shenkuoa caloneura & 5.23 & 132.35 & $\begin{array}{l}\text { Hauterivian-Early } \\
\text { Barremian }\end{array}$ & $\begin{array}{l}\text { Chengzihe Formation, } \\
\text { near Jixi, China }\end{array}$ \\
\hline $\begin{array}{l}\text { eudicot-like leaf, } \\
\text { chloranthoid teeth }\end{array}$ & 2.45 & 127.5 & Late Barremian & $\begin{array}{l}\text { La HuŽrguina } \\
\text { Formation, Las Hoyas } \\
\text { locality, Iberian Ranges, } \\
\text { Spain }\end{array}$ \\
\hline $\begin{array}{l}\text { Protoeaephyllum } \\
\text { (nymphaeoid leaf) }\end{array}$ & 4.28 & 127.5 & Late Barremian & $\begin{array}{l}\text { La HuŽrguina } \\
\text { Formation, Las Hoyas } \\
\text { locality, Iberian Ranges, } \\
\text { Spain }\end{array}$ \\
\hline Ficophyllum sp. & 1.96 & 127.5 & Late Barremian & $\begin{array}{l}\text { La HuŽrguina } \\
\text { Formation, Las Hoyas } \\
\text { locality, Iberian Ranges, } \\
\text { Spain }\end{array}$ \\
\hline Endressinia brasiliana & 5.23 & 119 & Late Aptian & Crato Formation, Brasil \\
\hline Araripia & 4.12 & 119 & Late Aptian & Crato Formation, Brasil \\
\hline "broad" angiosperm & 3.37 & 119 & Late Aptian & Crato Formation, Brasil \\
\hline "narrow" angiosperm & 4.56 & 119 & Late Aptian & Crato Formation, Brasil \\
\hline Pluricarpellatia & 2.39 & 119 & Late Aptian & Crato Formation, Brasil \\
\hline Nymphioid Crato Fossil & 1.23 & 119 & Late Aptian & Crato Formation, Brasil \\
\hline Longstrethia aspera & 3.654 & 102.7 & Late Albian & $\begin{array}{l}\text { Hoisington III, Dakota } \\
\text { Formation, KS, USA }\end{array}$ \\
\hline Liriophyllum kansense & 5.76 & 102.7 & Late Albian & $\begin{array}{l}\text { Hoisington III, Dakota } \\
\text { Formation, KS, USA }\end{array}$ \\
\hline Nelumbintes crassinervum & 3.12 & 102.7 & Late Albian & $\begin{array}{l}\text { Hoisington III, Dakota } \\
\text { Formation, KS, USA }\end{array}$ \\
\hline $\begin{array}{l}\text { Crassideniticulum } \\
\text { decurrens }\end{array}$ & 3.61 & 102.7 & Late Albian & $\begin{array}{l}\text { Hoisington III, Dakota } \\
\text { Formation, KS, USA }\end{array}$ \\
\hline Wolfiophyllum pfaffiana & 3.45 & 102.7 & Late Albian & $\begin{array}{l}\text { Hoisington III, Dakota } \\
\text { Formation, KS, USA }\end{array}$ \\
\hline Rogersia potteri & 3.46 & 102.7 & Late Albian & $\begin{array}{l}\text { Hoisington III, Dakota } \\
\text { Formation, KS, USA }\end{array}$ \\
\hline Rogersia kansense & 3.89 & 102.7 & Late Albian & $\begin{array}{l}\text { Hoisington III, Dakota } \\
\text { Formation, KS, USA }\end{array}$ \\
\hline Credneria cyclophylla & 7.84 & 102.7 & Late Albian & $\begin{array}{l}\text { Hoisington III, Dakota } \\
\text { Formation, KS, USA }\end{array}$ \\
\hline
\end{tabular}




\begin{tabular}{|c|c|c|c|c|}
\hline Sapindopsis bagleyae & 7.12 & 102.7 & Late Albian & $\begin{array}{l}\text { Hoisington III, Dakota } \\
\text { Formation, KS, USA }\end{array}$ \\
\hline Sapindopsis retallackii & 7.75 & 102.7 & Late Albian & $\begin{array}{l}\text { Hoisington III, Dakota } \\
\text { Formation, KS, USA }\end{array}$ \\
\hline Anisodromum wolfei & 6.56 & 102.7 & Late Albian & $\begin{array}{l}\text { Hoisington III, Dakota } \\
\text { Formation, KS, USA }\end{array}$ \\
\hline $\begin{array}{l}\text { Dicotylophyllum } \\
\text { leptovena }\end{array}$ & 5.5 & 102.7 & Late Albian & $\begin{array}{l}\text { Hoisington III, Dakota } \\
\text { Formation, KS, USA }\end{array}$ \\
\hline $\begin{array}{l}\text { Meiophyllum } \\
\text { expansolobum }\end{array}$ & 7.5 & 102.7 & Late Albian & $\begin{array}{l}\text { Hoisington III, Dakota } \\
\text { Formation, KS, USA }\end{array}$ \\
\hline Meiophyllum kowalskiae & 6.47 & 102.7 & Late Albian & $\begin{array}{l}\text { Hoisington III, Dakota } \\
\text { Formation, KS, USA }\end{array}$ \\
\hline Rogersia parlatorii & 3.27 & 102.7 & Late Albian & $\begin{array}{l}\text { Braun's Ranch, Dakota } \\
\text { Formation, KS, USA }\end{array}$ \\
\hline $\begin{array}{l}\text { Crassidenticulum } \\
\text { decurrens }\end{array}$ & 3.61 & 102.7 & Late Albian & $\begin{array}{l}\text { Braun's Ranch, Dakota } \\
\text { Formation, KS, USA }\end{array}$ \\
\hline Crassidenticulum landisae & 3.37 & 102.7 & Late Albian & $\begin{array}{l}\text { Braun's Ranch, Dakota } \\
\text { Formation, KS, USA }\end{array}$ \\
\hline $\begin{array}{l}\text { Trochodendroides } \\
\text { elliptica }\end{array}$ & 4.64 & 102.7 & Late Albian & $\begin{array}{l}\text { Braun's Ranch, Dakota } \\
\text { Formation, KS, USA }\end{array}$ \\
\hline Eoplatanus serrata & 7.84 & 102.7 & Late Albian & $\begin{array}{l}\text { Braun's Ranch, Dakota } \\
\text { Formation, KS, USA }\end{array}$ \\
\hline Credneria quadrata & 8.56 & 102.7 & Late Albian & $\begin{array}{l}\text { Braun's Ranch, Dakota } \\
\text { Formation, KS, USA }\end{array}$ \\
\hline $\begin{array}{l}\text { Aspidiophyllum } \\
\text { denticulatum }\end{array}$ & 8.46 & 102.7 & Late Albian & $\begin{array}{l}\text { Braun's Ranch, Dakota } \\
\text { Formation, KS, USA }\end{array}$ \\
\hline Hickeyphyllum imhofii & 3.36 & 102.7 & Late Albian & $\begin{array}{l}\text { Braun's Ranch, Dakota } \\
\text { Formation, KS, USA }\end{array}$ \\
\hline Dicotylophyllum braunii & 5.45 & 102.7 & Late Albian & $\begin{array}{l}\text { Braun's Ranch, Dakota } \\
\text { Formation, KS, USA }\end{array}$ \\
\hline $\begin{array}{l}\text { Wolfiophyllum } \\
\text { daphneoides }\end{array}$ & 4.23 & 102.7 & Late Albian & $\begin{array}{l}\text { Braun's Ranch, Dakota } \\
\text { Formation, KS, USA }\end{array}$ \\
\hline Dicotylophyllum huangi & 8.76 & 102.7 & Late Albian & $\begin{array}{l}\text { Braun's Ranch, Dakota } \\
\text { Formation, KS, USA }\end{array}$ \\
\hline Dicotylophyllum sp. & 4.88 & 102.7 & Late Albian & $\begin{array}{l}\text { Braun's Ranch, Dakota } \\
\text { Formation, KS, USA }\end{array}$ \\
\hline Wolfiophyllum heigii & 4.12 & 102.7 & Late Albian & $\begin{array}{l}\text { Braun's Ranch, Dakota } \\
\text { Formation, KS, USA }\end{array}$ \\
\hline Rogersia lottii & 4.65 & 102.7 & Late Albian & $\begin{array}{l}\text { Braun's Ranch, Dakota } \\
\text { Formation, KS, USA }\end{array}$ \\
\hline Jarzenia kanbrasota & 7.84 & 95.4 & Cenomanian & $\begin{array}{l}\text { Courtland, Dakota } \\
\text { Formation, MN, USA }\end{array}$ \\
\hline
\end{tabular}




\begin{tabular}{|c|c|c|c|c|}
\hline Dennsinervum kaulii & 4.05 & 95.4 & Cenomanian & $\begin{array}{l}\text { Courtland, Dakota } \\
\text { Formation, MN, USA }\end{array}$ \\
\hline $\begin{array}{l}\text { Crassidenticulum } \\
\text { cracendentis }\end{array}$ & 4.61 & 95.4 & Cenomanian & $\begin{array}{l}\text { Courtland, Dakota } \\
\text { Formation, MN, USA }\end{array}$ \\
\hline Manchesterii macrophylla & 8.34 & 95.4 & Cenomanian & $\begin{array}{l}\text { Courtland, Dakota } \\
\text { Formation, MN, USA }\end{array}$ \\
\hline $\begin{array}{l}\text { Pandemophyllum } \\
\text { attenuatum }\end{array}$ & 6.51 & 95.4 & Cenomanian & $\begin{array}{l}\text { Courtland, Dakota } \\
\text { Formation, MN, USA }\end{array}$ \\
\hline Setterholmia rotundifolia & 6.54 & 95.4 & Cenomanian & $\begin{array}{l}\text { Courtland, Dakota } \\
\text { Formation, MN, USA }\end{array}$ \\
\hline Wolfiophyllum pfaffiana & 4.8 & 95.4 & Cenomanian & $\begin{array}{l}\text { Courtland, Dakota } \\
\text { Formation, MN, USA }\end{array}$ \\
\hline Rogersia dakotensis & 3.84 & 95.4 & Cenomanian & $\begin{array}{l}\text { Courtland, Dakota } \\
\text { Formation, MN, USA }\end{array}$ \\
\hline $\begin{array}{l}\text { Trochodendroides } \\
\text { rhomboideus }\end{array}$ & 5.6 & 95.4 & Cenomanian & $\begin{array}{l}\text { Courtland, Dakota } \\
\text { Formation, MN, USA }\end{array}$ \\
\hline Credneria cyclophylla & 7.89 & 95.4 & Cenomanian & $\begin{array}{l}\text { Courtland, Dakota } \\
\text { Formation, MN, USA }\end{array}$ \\
\hline $\begin{array}{l}\text { Dicotylophyllum } \\
\text { coughlantia }\end{array}$ & 8.45 & 95.4 & Cenomanian & $\begin{array}{l}\text { Courtland, Dakota } \\
\text { Formation, MN, USA }\end{array}$ \\
\hline Setterholmia deleta & 6.12 & 95.4 & Cenomanian & $\begin{array}{l}\text { Courtland, Dakota } \\
\text { Formation, MN, USA }\end{array}$ \\
\hline Lysichiton austriacus & 3.45 & 77.05 & Campanian & Grunbach Austria \\
\hline Pandanites trinervis & 4.51 & 77.05 & Campanian & Grunbach Austria \\
\hline Sabalites longirhachis & 7.45 & 77.05 & Campanian & Grunbach Austria \\
\hline Monocotylophyllum sp. 1 & 5.65 & 77.05 & Campanian & Grunbach Austria \\
\hline $\begin{array}{l}\text { Compositiphyllum } \\
\text { serratum }\end{array}$ & 8.12 & 77.05 & Campanian & Grunbach Austria \\
\hline Grebenkia eurpoaea & 6.68 & 77.05 & Campanian & Grunbach Austria \\
\hline $\begin{array}{l}\text { Juglandiphyllites } \\
\text { cretaceus }\end{array}$ & 8.14 & 77.05 & Campanian & Grunbach Austria \\
\hline Brasenites krasseri & 7.12 & 77.05 & Campanian & Grunbach Austria \\
\hline $\begin{array}{l}\text { Dicotylophyllum } \\
\text { proteodies }\end{array}$ & 9.45 & 77.05 & Campanian & Grunbach Austria \\
\hline $\begin{array}{l}\text { Dicotylophyllum species } \\
5\end{array}$ & 7.91 & 77.05 & Campanian & Grunbach Austria \\
\hline $\begin{array}{l}\text { Ettinghausenia } \\
\text { gruenbachiana }\end{array}$ & 7.8 & 77.05 & Campanian & Grunbach Austria \\
\hline GD01-20223-1 & 8.59 & 69 & Maastrictian & Guadas, Colombia \\
\hline GD02-21092-1 & 11.72 & 69 & Maastrictian & Guadas, Colombia \\
\hline GD06-20753-2 & 11.95 & 69 & Maastrictian & Guadas, Colombia \\
\hline
\end{tabular}




\begin{tabular}{|c|c|c|c|c|}
\hline GD08-20956-1 & 12.34 & 69 & Maastrictian & Guadas, Colombia \\
\hline GD08-20975-2 & 12.41 & 69 & Maastrictian & Guadas, Colombia \\
\hline GD08-21266-2 & 14.74 & 69 & Maastrictian & Guadas, Colombia \\
\hline GD23 & 13.21 & 69 & Maastrictian & Guadas, Colombia \\
\hline GD35-20808-35 & 12.2 & 69 & Maastrictian & Guadas, Colombia \\
\hline GD50 & 7.33 & 69 & Maastrictian & Guadas, Colombia \\
\hline GD53-20353-1 & 11.5 & 69 & Maastrictian & Guadas, Colombia \\
\hline GD54-20559-4 & 15.42 & 69 & Maastrictian & Guadas, Colombia \\
\hline GD56 & 10.03 & 69 & Maastrictian & Guadas, Colombia \\
\hline CJ10 & 7.45 & 58 & Paleocene & $\begin{array}{l}\text { Cerrejon Formation, } \\
\text { Colombia }\end{array}$ \\
\hline CJ20 & 9.87 & 58 & Paleocene & $\begin{array}{l}\text { Cerrejon Formation, } \\
\text { Colombia }\end{array}$ \\
\hline CJ12 & 8.63 & 58 & Paleocene & $\begin{array}{l}\text { Cerrejon Formation, } \\
\text { Colombia }\end{array}$ \\
\hline CJ13 & 8.18 & 58 & Paleocene & $\begin{array}{l}\text { Cerrejon Formation, } \\
\text { Colombia }\end{array}$ \\
\hline CJ6 & 12.56 & 58 & Paleocene & $\begin{array}{l}\text { Cerrejon Formation, } \\
\text { Colombia }\end{array}$ \\
\hline $\mathrm{CJ} 3$ & 7.88 & 58 & Paleocene & $\begin{array}{l}\text { Cerrejon Formation, } \\
\text { Colombia }\end{array}$ \\
\hline CJ19 & 10.15 & 58 & Paleocene & $\begin{array}{l}\text { Cerrejon Formation, } \\
\text { Colombia }\end{array}$ \\
\hline CJ20 & 7.34 & 58 & Paleocene & $\begin{array}{l}\text { Cerrejon Formation, } \\
\text { Colombia }\end{array}$ \\
\hline CJ30 & 7.15 & 58 & Paleocene & $\begin{array}{l}\text { Cerrejon Formation, } \\
\text { Colombia }\end{array}$ \\
\hline CJ58 & 6.66 & 58 & Paleocene & $\begin{array}{l}\text { Cerrejon Formation, } \\
\text { Colombia }\end{array}$ \\
\hline CJ40 & 13.9 & 58 & Paleocene & $\begin{array}{l}\text { Cerrejon Formation, } \\
\text { Colombia }\end{array}$ \\
\hline CJ22 & 10.26 & 58 & Paleocene & $\begin{array}{l}\text { Cerrejon Formation, } \\
\text { Colombia }\end{array}$ \\
\hline CJ23 & 2.34 & 58 & Paleocene & $\begin{array}{l}\text { Cerrejon Formation, } \\
\text { Colombia }\end{array}$ \\
\hline CJ24 & 6.67 & 58 & Paleocene & $\begin{array}{l}\text { Cerrejon Formation, } \\
\text { Colombia }\end{array}$ \\
\hline CJ25 & 10.3 & 58 & Paleocene & $\begin{array}{l}\text { Cerrejon Formation, } \\
\text { Colombia }\end{array}$ \\
\hline CJ27 & 10.8 & 58 & Paleocene & $\begin{array}{l}\text { Cerrejon Formation, } \\
\text { Colombia }\end{array}$ \\
\hline
\end{tabular}




\begin{tabular}{|l|c|c|l|l|}
\hline CJ28 & 10.56 & 58 & Paleocene & $\begin{array}{l}\text { Cerrejon Formation, } \\
\text { Colombia }\end{array}$ \\
\hline CJ32 & 8.23 & 58 & Paleocene & $\begin{array}{l}\text { Cerrejon Formation, } \\
\text { Colombia }\end{array}$ \\
\hline CJ43 & 8.62 & 58 & Paleocene & $\begin{array}{l}\text { Cerrejon Formation, } \\
\text { Colombia }\end{array}$ \\
\hline CJ49 & 4.04 & 58 & Paleocene & $\begin{array}{l}\text { Cerrejon Formation, } \\
\text { Colombia }\end{array}$ \\
\hline CJ58 & 6.5 & 58 & Paleocene & $\begin{array}{l}\text { Cerrejon Formation, } \\
\text { Colombia }\end{array}$ \\
\hline CJ53 & 10.44 & 58 & Paleocene & $\begin{array}{l}\text { Cerrejon Formation, } \\
\text { Colombia }\end{array}$ \\
\hline CJ82 & 15.65 & 58 & Paleocene & $\begin{array}{l}\text { Cerrejon Formation, } \\
\text { Colombia }\end{array}$ \\
\hline CJ84 & 10.27 & 58 & Paleocene & $\begin{array}{l}\text { Cerrejon Formation, } \\
\text { Colombia }\end{array}$ \\
\hline CJ55 & 14 & 58 & Paleocene & $\begin{array}{l}\text { Cerrejon Formation, } \\
\text { Colombia }\end{array}$ \\
\hline CJ82 & 15.71 & 58 & Paleocene & $\begin{array}{l}\text { Cerrejon Formation, } \\
\text { Colombia }\end{array}$ \\
\hline CJ84 & 10.27 & 58 & Paleocene & $\begin{array}{l}\text { Cerrejon Formation, } \\
\text { Colombia }\end{array}$ \\
\hline CJ62 & 5.7 & 58 & Paleocene & $\begin{array}{l}\text { Cerrejon Formation, } \\
\text { Colombia }\end{array}$ \\
\hline CJ63 & 58 & Paleocene & $\begin{array}{l}\text { Cerrejon Formation, } \\
\text { Colombia }\end{array}$ \\
\hline CJ65 & 58 & Paleocene & $\begin{array}{l}\text { Cerrejon Formation, } \\
\text { Colombia }\end{array}$ \\
\hline CJ108 & 58 & Paleocene & $\begin{array}{l}\text { Cerrejon Formation, } \\
\text { Colombia }\end{array}$ \\
\hline
\end{tabular}

Morphotype: name or ID of each morphotypes

DVP: vein density

AGE1: Age in million years

AGE2: Geologic age (Cretaceous) or epoch (Paleocene), using the 2012 Geologic Time Scale

Formation: Name of the formation where the fossil comes from 